\title{
Synthesis and structure elucidation of novel pyrazolyl-2-pyrazolines obtained by the reaction of 3-(3-aryl-3-oxopropenyl)chromen-4-ones with phenylhydrazine
}

\author{
Clementina M. M. Santos, ${ }^{a}$ Artur M. S. Silva, ${ }^{b^{*}}$ József Jekő $^{c}$ and Albert Lévai ${ }^{d^{*}}$ \\ ${ }^{a}$ Department of Vegetal Production and Technology, School of Agriculture, Polytechnic Institute \\ of Bragança, 5301-855 Bragança, Portugal \\ ${ }^{b}$ Department of Chemistry \& QOPNA, University of Aveiro, 3810-193 Aveiro, Portugal \\ ${ }^{c}$ Department of Chemistry, College of Nyíregyháza, Sóstói u. 31/b, H-4400 Nyíregyháza, \\ Hungary \\ ${ }^{d}$ Department of Organic Chemistry, University of Debrecen, P. O. Box 20, H-4010 Debrecen, \\ Hungary \\ E-mail: artur.silva@ua.pt, alevai@puma.unideb.hu
}

\section{Dedicated to Professor Furenc Fülöp on the occasion of his $60^{\text {th }}$ birthday}

\begin{abstract}
Novel 3-aryl-5-\{4-[5-(2-hydroxyphenyl)-1-phenylpyrazolyl]\}-2-pyrazolines 2a-g have been prepared by the treatment of 3-(3-aryl-3-oxopropenyl)chromen-4-ones 1a-g with phenylhydrazine in refluxing acetic acid. NMR studies on deuteriochloroform solutions of pyrazolyl-2-pyrazolines $\mathbf{2 a - g}$ at different temperatures showed that at room temperature a mixture of diastereomers are present. This diastereoselectivity arises from the combination of the pyrazoline C-4 stereocenter and two planar chiral subunits due to internal steric hindrance. The energy barriers of this steric hindrance were overcome in DMSO- $\mathrm{d}_{6}$ solutions at $60^{\circ} \mathrm{C}$. The acetylation of some pyrazolyl-2-pyrazoline derivatives 2a-c,e helped to confirm the presence of the referred mixture of diastereomers.
\end{abstract}

Keywords: Chromones, phenylhydrazine, bispyrazoles, 4-pyrazolyl-2-pyrazolines, diastereomers, planar chirality, NMR spectroscopy

\section{Introduction}

Pyrazoles are interesting five-membered nitrogen heterocyclic compounds due to their synthetic versatility and broad spectrum of biological properties. ${ }^{1}$ Numerous derivatives have been found to act as pharmacodynamic and chemotherapeutic agents and also playing an important role on 
the central nervous system. ${ }^{2}$ On the other hand, the syntheses and selective functionalization of pyrazoles have stimulated the research over the years. Classical methods for the synthesis of substituted pyrazoles involve approaches based either in condensations of hydrazines with 1,3dicarbonyl compounds and in the intermolecular [3+2] cycloaddition reactions of 1,3-dipoles to alkynes. However, other methodologies have been developed for the preparation of novel substituted pyrazole-type compounds. ${ }^{1}$

3-(3-Aryl-3-oxopropenyl)chromen-4-ones 1 are useful $\alpha, \beta$-unsaturated ketones ${ }^{3}$ that can be used as starting materials in the synthesis of a wide variety of nitrogen-containing heterocyclic compounds. 4-Aryl-2-(3-chromonyl)-2,3-dihydro-1,5-benzothiazepines were synthesized by the reaction of 1 with 2-aminothiophenol, ${ }^{4}$ while the reaction with diazomethane afforded 3-aroyl-4(3-chromonyl)-2-pyrazolines ${ }^{5}$ similarly to that observed with $\alpha, \beta$-unsaturated ketones. Treating 3-(3-aryl-3-oxopropenyl)chromen-4-ones 1 with hydrazine hydrate provided several pyrazolyl-2pyrazolines, an interesting new pyrazoline-type compounds that were oxidized to bispyrazoles. ${ }^{6}$ These bis-azole derivatives are important biologically active compounds, since several pharmacological activities, such as anti-allergic, ${ }^{7}$ antifungal, ${ }^{8}$ anti-inflammatory, ${ }^{9}$ antitumor ${ }^{10}$ as well as cytotoxic properties ${ }^{11}$ have already been described.

In the continuation of an on-going research program devoted to the synthesis and characterization of these bis-heterocyclic ring systems, ${ }^{6,12}$ it seemed to be a challenging task to study the reaction of 3-(3-aryl-3-oxopropenyl)chromen-4-ones 1 with substituted hydrazines. Our work in this chemical transformation and a detailed NMR analysis of the structural features of the novel pyrazolyl-2-pyrazolines will be presented and discussed.

\section{Results and Discussion}

\section{Synthesis}

In a previous work, we reported that pyrazolyl-2-pyrazoline derivatives were obtained as the major products in the reaction of 3-(3-aryl-3-oxopropenyl)chromen-4-ones 1 with hydrazine hydrate in refluxing acetic acid. ${ }^{6}$ However, 1-acetyl-3-aryl-5-(3-chromonyl)-2-pyrazolines were also isolated as minor products (2-6\% yield). The isolation and characterization of these byproducts led to the reaction mechanism rationalization. It was postulated that the $\alpha, \beta$-unsaturated ketone moiety reacts first with one hydrazine molecule and then the chromone moiety reacts with a second molecule, leading to the formation of pyrazolyl-2-pyrazoline derivatives. ${ }^{6}$ Following this work and our interest on the synthesis and structural characterization of bis-1,2-azoles, ${ }^{6,12}$ we treated 3-(3-aryl-3-oxopropenyl)chromen-4-ones 1a-g with an excess of phenylhydrazine in refluxing acetic acid and novel pyrazolyl-2-pyrazolines $\mathbf{2 a - g}$ were obtained in good yields (6273\%) (Scheme 1). 


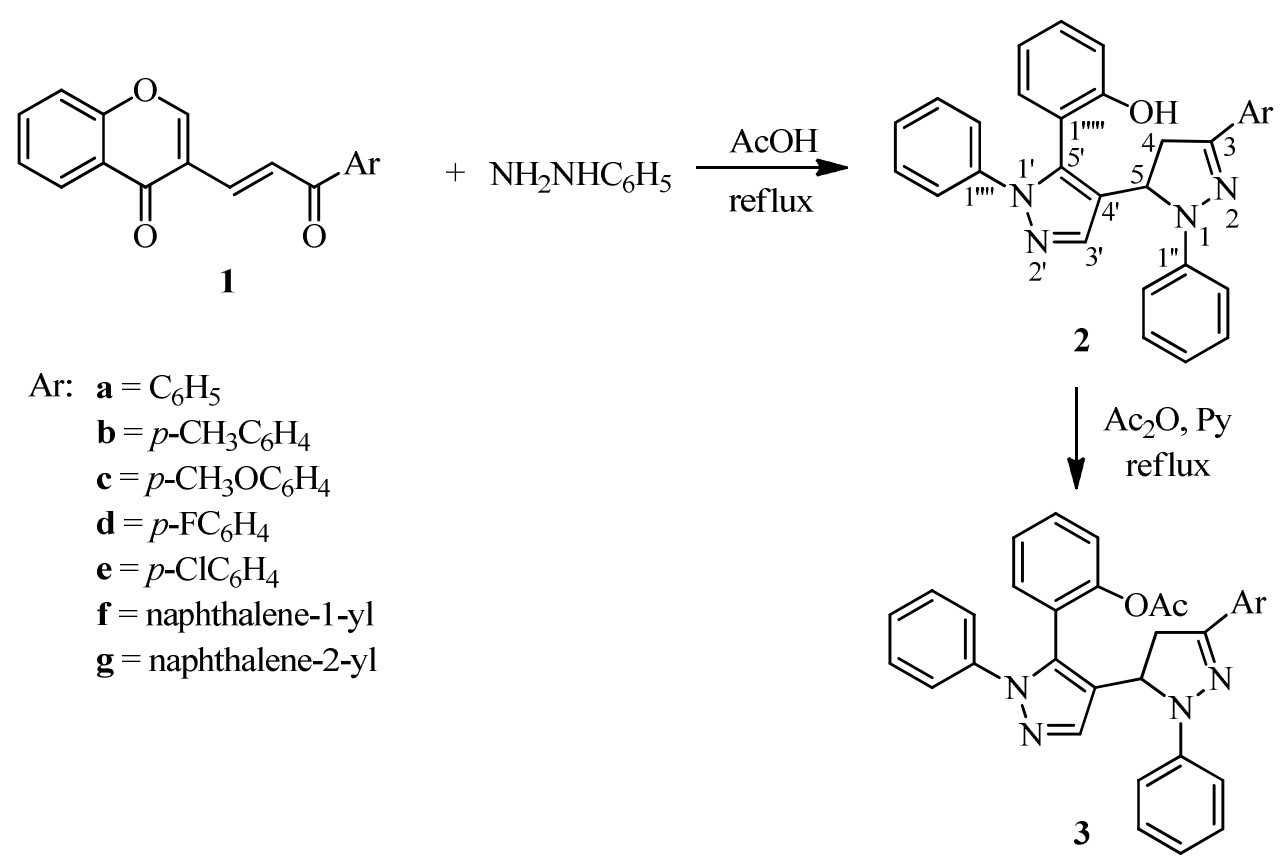

\section{Scheme 1}

Here, the formation of pyrazolyl-2-pyrazolines 2a-g also implies that both chromone and $\alpha, \beta$ unsaturated ketone moieties reacted with phenylhydrazine. Contrary to the referred previous work no by-products were isolated or detected even under careful chromatographic study. ${ }^{13}$ However, it can be postulated that (3-chromonyl)-2-pyrazoline-type compounds 4 are the primary reaction intermediates (Scheme 2). In a second reaction step these (3-chromonyl)-2pyrazolines 4 react with another molecule of phenylhydrazine to provide the final products 2 (Scheme 2). In this transformation the reaction of the chromone moiety with phenylhydrazine, a non symmetric hydrazine derivative, in acidic medium can proceed in two different ways, due to the equilibrium between the non protonated and protonated form of the more nucleophilic phenylhydrazine amino group (Scheme 2). In the former case, the more nucleophilic amino group attacks the chromone $\mathrm{C}-2$ carbon, in a conjugate-type addition, with consequent pyran ring opening leading to intermediates $\mathbf{5}$. Then, the intramolecular reaction between the other amino group (NHPh) and the carbonyl unit lead to pyrazolyl-2-pyrazoline derivatives 2 . In the protonated hydrazine molecule $\mathrm{NHPh}$ becomes the nucleophile attacking the chromone $\mathrm{C}-2$ carbon and after a pyran ring opening give rise to intermediates $\mathbf{6}$. The pyrazole ring may be formed by an intramolecular reaction between the other amino group of $\mathbf{7}$ and the carbonyl unit, resulting in the formation of compound $\mathbf{8}$. Our results indicate that the transformation proceeded by pathway a) of the reaction mechanism (Scheme 2). In fact, NHPh is a very week nucleophile implying that even in acidic medium, it is the more nucleophilic $\mathrm{NH}_{2}$ group that reacts with the chromone moiety. 


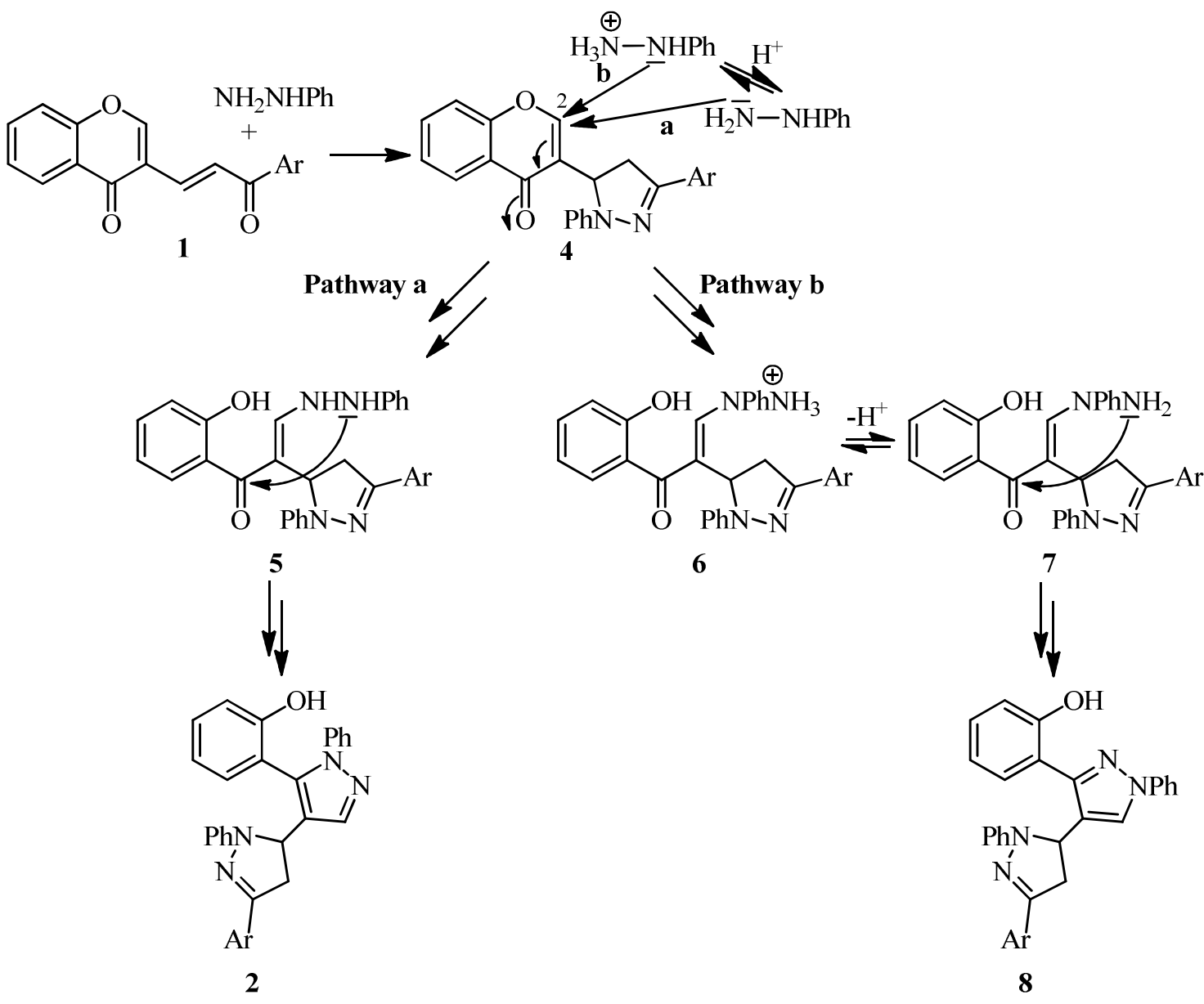

\section{Scheme 2}

To help the structural elucidation of the new synthesized 3-aryl-1-phenyl-5-\{4-[5-(2hydroxyphenyl)-1-phenylpyrazolyl]\}-2-pyrazolines 2a-g, some of them 2a-c,e were acetylated with acetic anhydride in refluxing pyridine to afford acetylated derivatives 3a-c,e (Scheme 1).

\section{Structure elucidation}

The structures of all new compounds have been elucidated by using elemental analysis, mass spectrometry, infrared spectrophotometry and an exhaustive NMR study. Elemental analysis and mass spectrometric measurements unequivocally prove the elemental composition of compounds 2a-g and 3a-c,e.

The ${ }^{1} \mathrm{H}$ NMR spectrum of pyrazolyl-2-pyrazoline $2 \mathrm{c}$ in $\mathrm{CDCl}_{3}$ at room temperature $\left(22^{\circ} \mathrm{C}\right)$ showed extreme line broadening for almost all signals in the aliphatic and aromatic regions. This line broadening is especially evident in the proton resonances of the 5'-hydroxyphenyl group, H3 ' and H-4, while H-5 appears as two broad signals centered at $\delta 4.99$ and $5.10 \mathrm{ppm}$. Raising the temperature to $50^{\circ} \mathrm{C}$ resulted in a clear sharpening of $\mathrm{H}-3$ ' and both $\mathrm{H}-4$ signals, while those of 
5'-hydroxyphenyl group remained broad and there was the coalescence of both H-5 signals. Decreasing the temperature to $5^{\circ} \mathrm{C}$, two sets of signals for the resonance of each proton were observed being easily identified in the aliphatic region (Figure 1). These data indicate that pyrazolyl-2-pyrazoline 2c exist as a mixture of diastereomers at room temperature in the chloroform solution. This diastereoselectivity arises from the combination of the pyrazoline C-4 stereocenter and two planar chiral subunits due to an internal possible hindered rotation involving the pyrazoline moiety and the 5'-hydroxyphenyl group. Under these conditions there is a slowly rotation between these moieties compared to the NMR time scale, reason why broad signals were observed in the ${ }^{1} \mathrm{H}$ and ${ }^{13} \mathrm{C}$ NMR spectra. ${ }^{14}$ At $5{ }^{\circ} \mathrm{C}$ the two diastereomers were frozen and shape signals for the resonances of each one of the isomers were observed.

Since the temperature of $50^{\circ} \mathrm{C}$ was not enough to overcome the energy barrier of the referred hindered rotation of compound $\mathbf{2 c}$ and the temperature could not be further increased (b.p. $\mathrm{CDCl}_{3}$ $=61^{\circ} \mathrm{C}$ ), DMSO- $\mathrm{d}_{6}$ was chosen as solvent to reach higher temperatures. In this case, once again, at temperatures between $22^{\circ} \mathrm{C}$ and $50^{\circ} \mathrm{C}$ some broad signals still appeared. Only at $60^{\circ} \mathrm{C}$ sharp resonances in the aliphatic and aromatic regions of both ${ }^{1} \mathrm{H}$ and ${ }^{13} \mathrm{C}$ NMR spectra were observed, indicating that the energy barrier was overcome and there was no more diastereomers, but a mixture of enantiomers. A maximum resolution spectrum of a DMSO- $\mathrm{d}_{6}$ solution of $2 \mathbf{c}$ was obtained at $80^{\circ} \mathrm{C}$ (Figure 2; vide experimental part).

From the described results it was decided to acquire the ${ }^{1} \mathrm{H}$ and ${ }^{13} \mathrm{C}$ NMR spectra of pyrazolyl-2-pyrazolines $\mathbf{2 a - g}$ at $5^{\circ} \mathrm{C}$ in $\mathrm{CDCl}_{3}$ allowing the structural characterization description of both diastereomers.

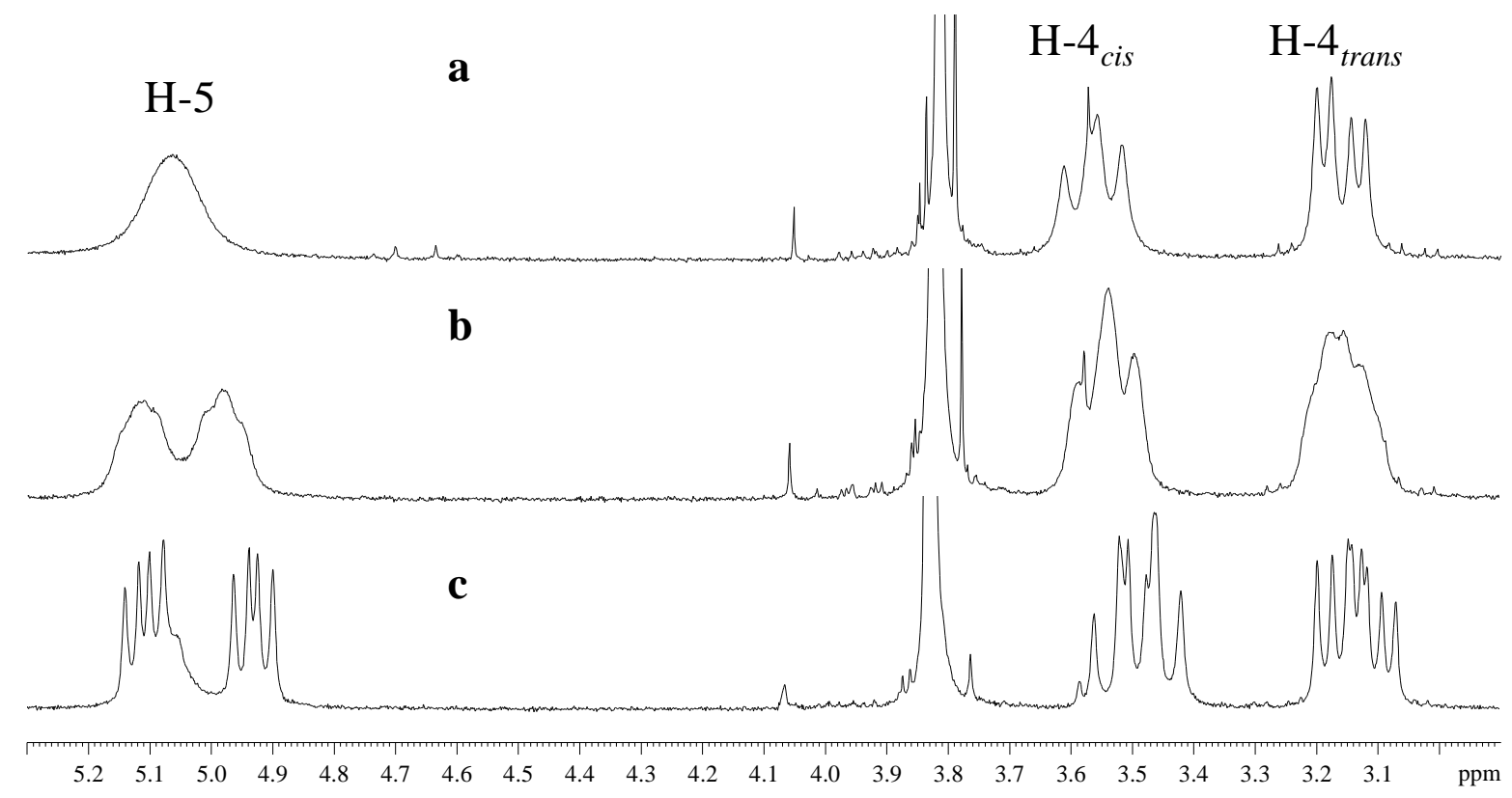

Figure 1. Aliphatic region of the ${ }^{1} \mathrm{H}$ NMR spectrum of pyrazolyl-2-pyrazoline $2 \mathrm{c}$ in $\mathrm{CDCl}_{3}$ : a) at $50^{\circ} \mathrm{C}$; b) at room temperature $\left(22^{\circ} \mathrm{C}\right)$; and c) at $5^{\circ} \mathrm{C}$. 


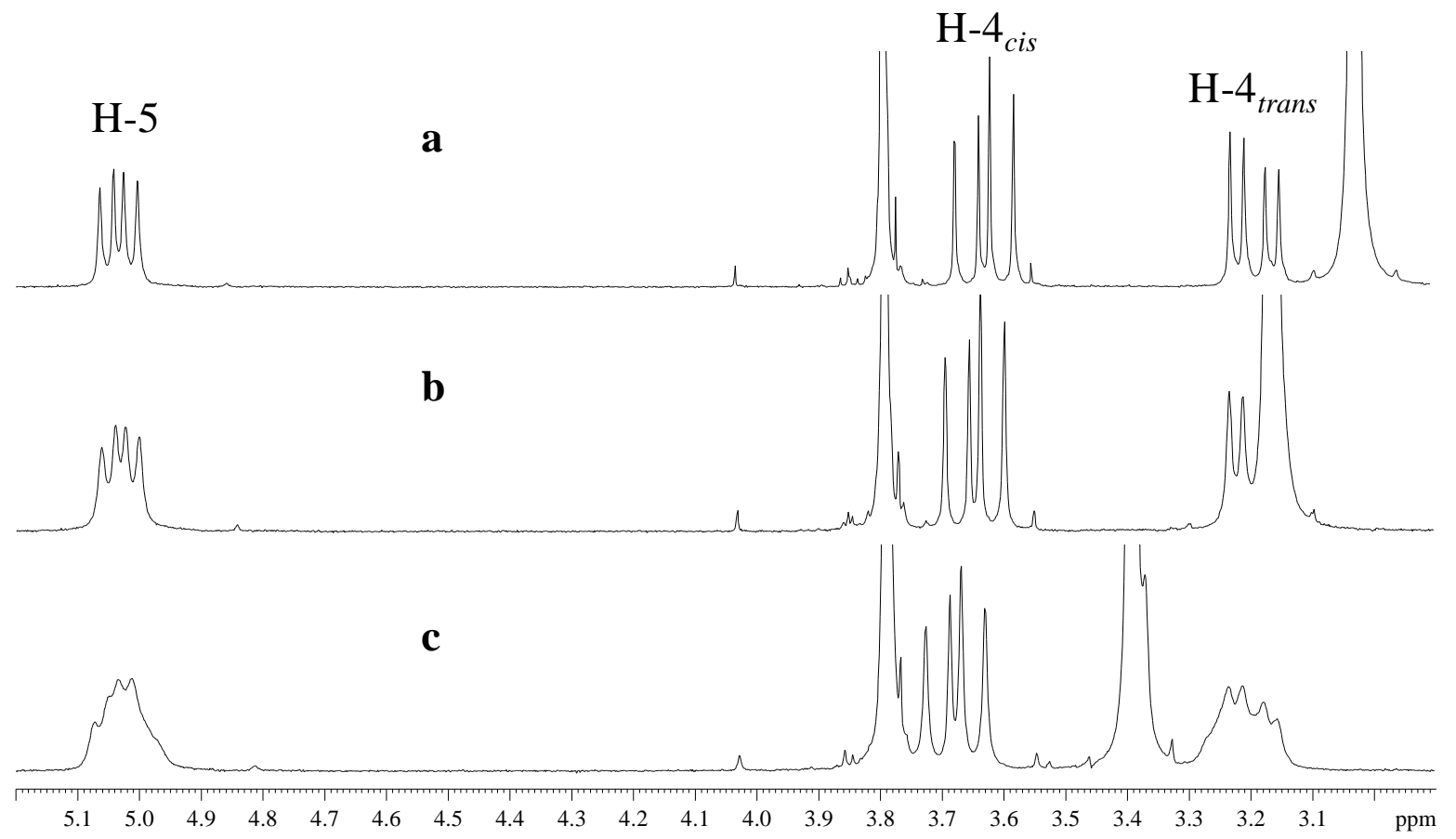

Figure 2. Aliphatic region of the ${ }^{1} \mathrm{H}$ NMR spectrum of pyrazolyl-2-pyrazoline $2 \mathrm{c}$ in DMSO- $\mathrm{d}_{6}$ : a) at $80^{\circ} \mathrm{C}$; b) at $60^{\circ} \mathrm{C}$ and c). at room temperature $\left(22^{\circ} \mathrm{C}\right)$

Although the aliphatic region of the ${ }^{1} \mathrm{H}$ NMR spectra of pyrazolyl-2-pyrazolines 2a-e presents two groups of three signals, due to the H-4 and H-5 resonances of both diastereomers, it was not possible to unequivocally assign their structures and ratio, being thus designated as diastereomer A and diastereomer B. Based on the analysis of 2D COSY and NOESY experiments, the proton resonances of the 2-pyrazoline ring of both diastereomers have been assigned: diastereomer A - H-4 ${ }_{\text {trans }} 15\left(\mathrm{dd}, \delta=3.07-3.14 \mathrm{ppm}, J_{\text {gem }}=16-17 \mathrm{~Hz}, J_{\text {trans }} \sim 7 \mathrm{~Hz}\right), \mathrm{H}-$ $4_{\text {cis }}\left(\mathrm{dd}, J_{\text {gem }}=16-17 \mathrm{~Hz}, J_{\text {cis }} \sim 12 \mathrm{~Hz}, \delta=3.47-3.55 \mathrm{ppm}\right)$ and $\mathrm{H}-5$ (dd, $\left.\delta=5.10-5.17 \mathrm{ppm}\right)$; diastereomer B - H- $4_{\text {trans }}{ }^{13}\left(\mathrm{dd}, \delta=3.13-3.20 \mathrm{ppm}, J_{\text {gem }}=17-18 \mathrm{~Hz}, J_{\text {trans }}=7-8 \mathrm{~Hz}\right), \mathrm{H}-4_{\text {cis }}(\mathrm{dd}$, $\left.J_{\text {gem }}=17-18 \mathrm{~Hz}, J_{\text {cis }}=12-13 \mathrm{~Hz}, \delta=3.41-3.51 \mathrm{ppm}\right)$ and $\mathrm{H}-5$ (dd, $\left.\delta=4.93-4.98 \mathrm{ppm}\right)$. In the case of compounds $\mathbf{2 f}, \mathbf{g}$, the presence of the naphthyl group shifted the $\mathrm{H}-4_{\text {cis }}$ and $\mathrm{H}-4_{\text {trans }}$ resonances for higher frequency values $(\Delta \delta \approx+0.2 \mathrm{ppm})$ when compared with those of $2 \mathrm{a}-\mathbf{e}$. The proton resonance of pyrazole H-3' of both isomers have been assigned to the two singlets at $\delta=$ 7.57-7.63 ppm for compounds 2a-e and $\delta=7.62-7.66 \mathrm{ppm}$ for compounds $\mathbf{2 f}$,g (except for derivative $2 \mathrm{c}$ that appear as only one singlet at $\delta=7.63 \mathrm{ppm}$ ).

The complexity of the aromatic region in the ${ }^{1} \mathrm{H}$ NMR spectra of pyrazolyl-2-pyrazolines $\mathbf{2 a -}$ $\mathrm{g}$ did not allow to unequivocally assign the proton resonances of each one of the diastereomers A and B. However, the 2D NMR experiments (COSY, NOESY, HSQC and HMBC spectra) permitted to assign each proton of both diastereomers. The most easily identified are the proton resonances to the 3-aryl group. In fact, in the case of compounds 2a-e H-2"',6", appeared at high 
values of frequency, $\delta=7.55-7.66 \mathrm{ppm}$, due to the deshielding anisotropic effect of the $\mathrm{C}=\mathrm{N}$ pyrazoline bond. These assignments were also confirmed by the strong NOE cross peaks observed in the NOESY spectra between these protons and those of 4- $\mathrm{CH}_{2}$. The remaining proton resonances of this 3-aryl ring were assigned based on the 2D COSY correlations. The proton assignments of the 1-phenyl group were based on the strong NOE cross peaks between the signal of H-5 and those of H-2',6', complemented by the correlations observed in the 2D COSY spectra.

It is also worth to mention the $\mathrm{OH}$ proton resonance appearing as a broad singlet $(\delta 5.08-5.20$ ppm) in the ${ }^{1} \mathrm{H}$ NMR spectra of the para-substituted compounds $\mathbf{2 b - e}$.

The HSQC spectra allowed the assignment of all protonated carbons of $\mathbf{2 a - g}$, while the HMBC connectivities permitted to confirm some of them and to assign those of the quaternary carbons (Figure 3). In fact, the main HMBC connectivities of 2a-e were: 4- $\mathrm{CH}_{2}, \mathrm{H}-5$ and $\mathrm{H}$ 2" ,6" $\rightarrow$ C-3 $\left(\delta_{\mathrm{C}}=145.8-148.3 \mathrm{ppm}\right)$; H-5 $\rightarrow$ C-3' $\left(\delta_{\mathrm{C}}=138.3-139.1 \mathrm{ppm}\right)$; 4-CH $\mathrm{C}_{2}$ and H-3' $\rightarrow$ C-4' $\left(\delta_{\mathrm{C}}=123.9-124.1 \mathrm{ppm}\right)$; H-5 and H-3' $\rightarrow$ C-5' $\left(\delta_{\mathrm{C}}=135.8-136.5 \mathrm{ppm}\right)$.

The $\mathrm{OH}$ acetylation of derivatives $\mathbf{2 a - c , e ~ p r o m o t e d ~ a ~ b e t t e r ~ r e s o l u t i o n ~ o f ~ t h e ~}{ }^{1} \mathrm{H}$ NMR spectra (mainly in the aromatic region) of compounds 3a-c,e and permitted to assign the individual protons of each one of the diastereomers. Thus, it was also possible to assign the ratio of both diastereomers, based in the area of the methyl signals of the acetyl group. The proportion of both isomers as $52.0-54.5 \%$ and $45.5-48.0 \%$ led us to designate them as major and minor diastereomers, respectively (vide experimental part).

The main features of the NMR data of these acetylated derivatives 3a-c,e were the resonances of the acetyl $\left(\mathrm{CH}_{3}\right.$ at $\delta_{\mathrm{H}}=2.04-2.13 \mathrm{ppm}$ and $\left.\delta_{\mathrm{C}}=20.8-20.9 \mathrm{ppm}\right)$ and carbonyl at $\left(\delta_{\mathrm{C}}=168.3-168.6 \mathrm{ppm}\right)$ groups. Other important characteristics were the resonances of $\mathrm{H}-4_{\text {trans }} 15$ $(\delta=3.19-3.24 \mathrm{ppm})$ and $\mathrm{H}-5(\delta=5.15-5.23 \mathrm{ppm})$ of the major diastereomers appearing at higher frequency than those of the minor ones $(\delta=3.16-3.22$ and 5.07-5.15 ppm, respectively). In the case of $\mathrm{H}-4_{\text {cis }} 15$ the signal of the major diastereomer appeared at lower frequency $(\delta=3.62-3.66$ ppm) than that of the minor one $(\delta=3.68-3.74 \mathrm{ppm})$. The NOE cross peaks between the $4-\mathrm{CH}_{2}$ signals and the doublets at $\delta=7.60-7.75 \mathrm{ppm}$ and of the $\mathrm{H}-5$ and the doublets at $\delta=7.00-7.09$ ppm allowed to assign these chemical shifts to the resonances of H-2", 6" and H-2",6", respectively. The COSY correlations permitted to assign the other protons of these two aromatic rings. The assignment of the remaining proton and carbon resonances in the NMR spectra of 3ac,e unit was similar to that describe for compounds 2a-c,e and were based on the 2D NMR spectra (the main HMBC and NOESY correlations are presented in figure 3). 
HMBC

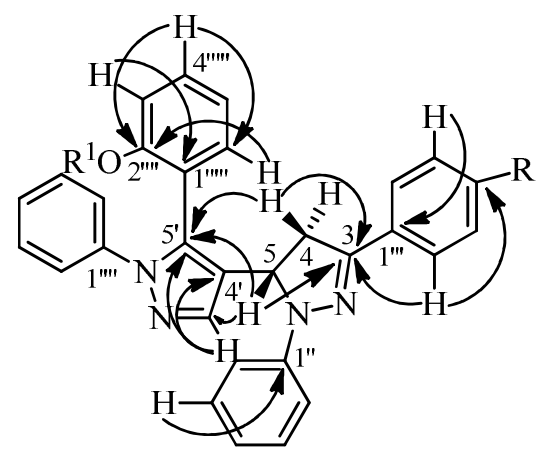

NOESY

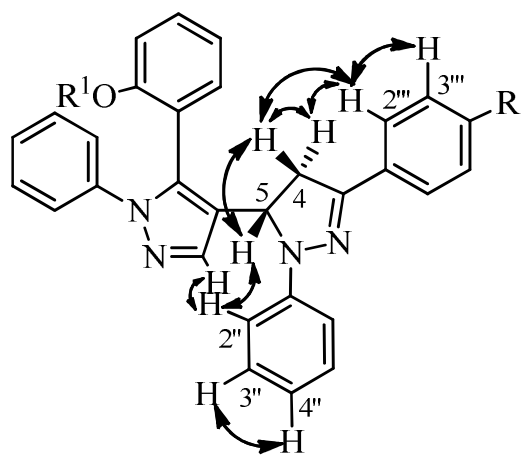

Figure 3. Main correlations observed in the HMBC and NOESY spectra of both diastereomers of pyrazolyl-2-pyrazolines 2a-g and 3a-c,e.

\section{Conclusion}

Following our work on pyrazoles we synthesised a new series of 3-aryl-5-\{4-[5-(2hydroxyphenyl)-1-phenylpyrazolyl]\}-2-pyrazolines 2a-g from the reaction of 3-(3-aryl-3oxopropenyl)chromen-4-ones 1a-g with phenylhydrazine in refluxing acetic acid. A study on the structural characterisation of these compounds by NMR at different temperatures showed a mixture of diastereomers at room temperature. The intramolecular hindered rotation combined with the pyrazoline C-4 stereocenter induces this diastereoselectivity, situation that are to the best of our knowledge reported for the first time.

\section{Experimental Section}

General. Melting points were determined on a Kofler hot-stage apparatus and are uncorrected. NMR spectra were recorded on Bruker Avance 300 spectrometer $\left(300.13 \mathrm{MHz}\right.$ for ${ }^{1} \mathrm{H}$ and 75.47 $\mathrm{MHz}$ for ${ }^{13} \mathrm{C}$ ), at $5^{\circ} \mathrm{C}$ with $\mathrm{CDCl}_{3}$ as solvent, if not stated otherwise. Chemical shifts $(\delta)$ are reported in ppm and coupling constants $(J)$ in $\mathrm{Hz}$; internal standard was TMS. ${ }^{1} \mathrm{H}$ assignments were made by $2 \mathrm{D} g \mathrm{COSY}$ and NOESY (mixing time $800 \mathrm{~ms}$ ) experiments, while ${ }^{13} \mathrm{C}$ assignments were made with the aid of 2D $g \mathrm{HSQC}$ and $g \mathrm{HMBC}$ (delays for one bond and longrange $J \mathrm{C} / \mathrm{H}$ couplings were optimised for 145 and $7 \mathrm{~Hz}$, respectively) experiments. The IR spectra were obtained with a Perkin-Elmer16 PC instrument. Mass spectra (CI) were recorded on a VG trio-2 apparatus. Elemental analyses ( $\mathrm{CHN})$ were measured in-house with a Carlo Erba 1106 instrument. TLC was performed on silica gel $60 \mathrm{~F}_{254}$ (Merck) layer using toluene: ethyl acetate $(4: 1, \mathrm{v} / \mathrm{v})$ as eluent. The starting materials 1a-g were synthesized according to known procedures. ${ }^{3}$ 


\section{General procedure for the synthesis of pyrazolyl-2-pyrazolines 2a-g}

A mixture of the appropriate 3-(3-aryl-3-oxopropenyl)chromen-4-ones 1a-g (5.0 mmoles), phenylhydrazine $(4.9 \mathrm{~mL}, 50.0$ mmoles $)$ and acetic acid $(50 \mathrm{~mL})$ was reflux for 3 hours and then poured into water $(100 \mathrm{~mL})$ and ice $(50 \mathrm{~g})$. The precipitate was filtrated, washed with water and recrystallized from methanol to obtain crystalline 3-aryl-5-\{4-[5-(2-hydroxy-phenyl)-1phenylpyrazolyl]\}-2-pyrazolines 2a-g (Scheme 1).

1,3-Diphenyl-5-\{4-[5-(2-hydroxyphenyl)-1-phenylpyrazolyl]\}-2-pyrazoline (2a). Obtained as white needles in $68 \%$ yield, m.p. $137-138^{\circ} \mathrm{C}$.

Diastereomeric mixture $-\mathrm{NMR}$ at $5^{\circ} \mathrm{C}$ :

Diastereomer A: ${ }^{1} \mathrm{H}$ NMR $\delta 3.14\left(\mathrm{dd}, 1 \mathrm{H}, J=6.7\right.$ and $\left.16.0 \mathrm{~Hz}, \mathrm{H}-4_{\text {trans }}\right), 3.54(\mathrm{dd}, 1 \mathrm{H}, J=12.1$ and $\left.16.0 \mathrm{~Hz}, \mathrm{H}-4_{\text {cis }}\right), 5.16$ (dd, $1 \mathrm{H}, J=6.7$ and $\left.12.1 \mathrm{~Hz}, \mathrm{H}-5\right)$.

Diastereomer B: ${ }^{1} \mathrm{H}$ NMR $\delta 3.20\left(\mathrm{dd}, 1 \mathrm{H}, J=7.1\right.$ and $\left.17.5 \mathrm{~Hz}, \mathrm{H}-4_{\text {trans }}\right), 3.51(\mathrm{dd}, 1 \mathrm{H}, J=11.8$ and $\left.17.5 \mathrm{~Hz}, \mathrm{H}-4_{c i s}\right), 4.98$ (dd, $1 \mathrm{H}, J=7.1$ and $\left.11.8 \mathrm{~Hz}, \mathrm{H}-5\right)$.

Diastereomers A+B: ${ }^{1} \mathrm{H}$ NMR $\delta 6.75$ (d, $1 \mathrm{H}, J=7.5 \mathrm{~Hz}, \mathrm{H}-3$ '”'), 6.73-6.89 (m, 4H, 2xH-4" and 2xH-5","'), 6.91 (d, $1 \mathrm{H}, J=8.2 \mathrm{~Hz}, \mathrm{H}-3$ ","”), 6.92-7.00 (m, $2 \mathrm{H}, 2 \mathrm{xH}-6$ "”,'), 7.01 (d, $2 \mathrm{H}, J=8.3$ $\mathrm{Hz}, \quad \mathrm{H}-2$ ",6"), 7.09-7.39 (m, 25 H, H-2",6"; 2xH-3",5"; 2xH-3",,4",5"'; 2xH2",',3"',4"',5",',6"', and 2xH-4","'), 7.59 and 7.62 (2s, 2 H, 2xH-3'), 7.660 and 7.664 (2d, 4 H, J $=7.8$ and $\left.8.1 \mathrm{~Hz}, 2 \mathrm{xH}-2 "{ }^{\prime \prime}, 6 "{ }^{\prime \prime}\right) .{ }^{13} \mathrm{C}$ NMR $\delta 42.0$ and $42.3(\mathrm{C}-4), 55.6$ and 56.3 (C-5), 113.6 and 113.8 (C-2",6"), 116.2, 116.4 and 116.5 (C-1"'” and C-3"'”'), 119.1 and 119.4 (C-4"), 120.4 and 120.7 (C-5"'”), 123.8 and 124.1 (C-2"',6"'), 124.0 (C-4'), 125.6 and 125.7 (C-2"',6"'), 127.3 (C-4"'”), 128.4, 128.6, 128.7 and 128.8 (C-3",5"; C-3"',4", 5"' and C-3"”,,5"'), 131.0 (C-4"'”), 131.3 and 131.7 (C-6”"'”), 132.3 and 132.6 (C-1'”), 135.9 and 136.2 (C-5'), 138.51 and 138.52 (C-3'), 139.2 and 139.4 (C-1'”'), 144.6 and 144.8 (C-1"), 147.1 and 148.0 (C-3), 153.9 and 154.5 (C-2'”'”). IR (cm $\left.{ }^{-1}\right): 1596,1502,1386,1334,1290,1178,1156,1014,758,692$; MS (EI $\left.70 \mathrm{eV}\right)$ : $m / z(\%)=456\left(\mathrm{M}^{+}, 78\right), 364(38), 261$ (47), 91 (100). Anal. Calcd. for $\mathrm{C}_{30} \mathrm{H}_{24} \mathrm{~N}_{4} \mathrm{O}: \mathrm{C}, 78.93 ; \mathrm{H}$, 5.30; N, 12.27. Found: C, 78.84; H, 5.36; N, 12.35 .

5\{4-[5-(2-Hydroxyphenyl)-1-phenylpyrazolyl]\}-3-(4-methylphenyl)-1-phenyl-2-pyrazoline (2b). Prepared as white needles in $66 \%$ yield, m.p. $154-155^{\circ} \mathrm{C}$.

Diastereomeric mixture $-\mathrm{NMR}$ at $5^{\circ} \mathrm{C}$ :

Diastereomer A: ${ }^{1} \mathrm{H}$ NMR $\delta 2.37\left(\mathrm{~s}, 3 \mathrm{H}, \mathrm{CH}_{3}\right), 3.13\left(\mathrm{dd}, 1 \mathrm{H}, J=6.6\right.$ and $16.4 \mathrm{~Hz}, \mathrm{H}-4_{\text {trans }}$ ), $3.55\left(\mathrm{dd}, 1 \mathrm{H}, J=12.1\right.$ and $\left.16.4 \mathrm{~Hz}, \mathrm{H}-4_{\text {cis }}\right), 5.13$ (dd, $1 \mathrm{H}, J=6.6$ and $\left.12.1 \mathrm{~Hz}, \mathrm{H}-5\right), 5.14$ (br s, $1 \mathrm{H}, \mathrm{OH})$.

Diastereomer B: ${ }^{1} \mathrm{H}$ NMR $\delta 2.37\left(\mathrm{~s}, 3 \mathrm{H}, \mathrm{CH}_{3}\right), 3.19\left(\mathrm{dd}, 1 \mathrm{H}, J=7.2\right.$ and $16.6 \mathrm{~Hz}, \mathrm{H}-4_{\text {trans }}$ ), $3.51\left(\mathrm{dd}, 1 \mathrm{H}, J=12.1\right.$ and $\left.16.6 \mathrm{~Hz}, \mathrm{H}-4_{\text {cis }}\right), 4.97(\mathrm{dd}, 1 \mathrm{H}, J=7.2$ and $12.1 \mathrm{~Hz}, \mathrm{H}-5), 5.14$ (br s, $1 \mathrm{H}, \mathrm{OH})$.

Diastereomers A+B: ${ }^{1} \mathrm{H}$ NMR $\delta$ 6.72-6.83 (m, $3 \mathrm{H}, 2 \mathrm{xH}-4$ " and H-3","'), 6.83-6.93 (m, $3 \mathrm{H}, \mathrm{H}-$ 3"," and 2xH-5","'), 6.94 (d, $1 \mathrm{H}, J=7.4 \mathrm{~Hz}, \mathrm{H}-6$ "',"), 6.99-7.03 (m, $3 \mathrm{H}, \mathrm{H}-2$ ",6" and H-6","'),

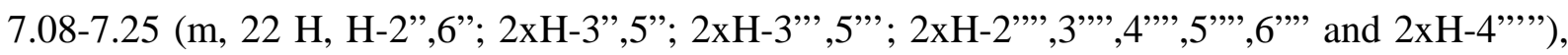


7.57 (d, $4 \mathrm{H}, J=7.9 \mathrm{~Hz}, 2 \mathrm{xH}-2$ "', 6"”), 7.60 and 7.63 (2s, $2 \mathrm{H}, 2 \mathrm{xH}-3$ ') ${ }^{13} \mathrm{C}$ NMR $\delta 21.4\left(\mathrm{CH}_{3}\right)$, 42.0 and 42.4 (C-4), 55.6 and 56.3 (C-5), 113.5 and 113.9 (C-2”,6”), 116.2, 116.5 and 116.6 (C1 "'” and C-3"'”'), 118.9 and 119.4 (C-4"), 120.5 and 120.7 (C-5"”'"), 123.7 and 124.3 (C2"',6"”'), 124.1 (C-4'), 125.6 and 125.7 (C-2"',6"'), 127.2 (C-4"”'), 128.7, 128.8 and 129.2 (C3",5"; C-3"',5"' and C-3"',5"”), 131.0 (C-4"”,'), 129.7 and 129.8 (C-1"'), 131.3 and 131.7 (C6"'”), 135.8 and 136.1 (C-5'), 138.5 and 138.7 (C-4”'), 138.6 (C-3'), 139.2 and 139.4 (C-1'”'), 144.7 and 145.0 (C-1"), 147.3 and 148.3 (C-3), 153.9 and 154.4 (C-2"'”'). IR (cm $\left.{ }^{-1}\right): 1598,1498$, 1380, 1320, 1230, 1182, 1156, 1122, 1068, 1034, 854, 692, 662; MS (EI $70 \mathrm{eV}): \mathrm{m} / z(\%)=470$ $\left(\mathrm{M}^{+}, 81\right), 247$ (19), 208 (19), 91 (100). Anal. Calcd. for $\mathrm{C}_{31} \mathrm{H}_{26} \mathrm{~N}_{4} \mathrm{O}: \mathrm{C}, 79.13 ; \mathrm{H}, 5.57 ; \mathrm{N}, 11.90$. Found: C, 79.22; H, 5.63; N, 11.82 .

\section{5-\{4-[5-(2-Hydroxyphenyl)-1-phenylpyrazolyl]\}-3-(4-methoxyphenyl)-1-phenyl-2-pyrazo-}

line (2c). Isolated as white plates in $64 \%$ yield, m.p. $142-143^{\circ} \mathrm{C}$.

${ }^{1} \mathrm{H}$ NMR (DMSO-d $\left.6,80^{\circ} \mathrm{C}\right) \delta 3.19\left(\mathrm{dd}, 1 \mathrm{H}, J=6.7\right.$ and $\left.17.1 \mathrm{~Hz}, \mathrm{H}-4_{\text {trans }}\right), 3.63(\mathrm{dd}, 1 \mathrm{H}, J=$ 11.6 and $17.1 \mathrm{~Hz}, \mathrm{H}-4$ cis), 3.79 (s, $\left.3 \mathrm{H}, \mathrm{OCH}_{3}\right), 5.03$ (dd, $1 \mathrm{H}, J=6.7$ and $\left.11.6 \mathrm{~Hz}, \mathrm{H}-5\right), 6.70$ (t, $1 \mathrm{H}, J=7.2 \mathrm{~Hz}, \mathrm{H}-4$ "), 6.84 (dd, $1 \mathrm{H}, J=7.4$ and $7.6 \mathrm{~Hz}, \mathrm{H}-5$ "','), 6.92 (d, $1 \mathrm{H}, J=8.5 \mathrm{~Hz}, \mathrm{H}-$ 3"'”), 6.96 (d, 2 H, $J=8.9 \mathrm{~Hz}, \mathrm{H}-3$ "',5”), 7.02 (d, $2 \mathrm{H}, J=8.3 \mathrm{~Hz}, \mathrm{H}-2 ", 6 ”), 7.05$ (dd, $1 \mathrm{H}, J=$ 1.8 and $7.6 \mathrm{~Hz}, \mathrm{H}-6$ "'”'), 7.12 (dd, $2 \mathrm{H}, J=7.2$ and 8.3 Hz, H-3",5”), 7.20-7.27 (m, $7 \mathrm{H}, \mathrm{H}-4$ ", H-

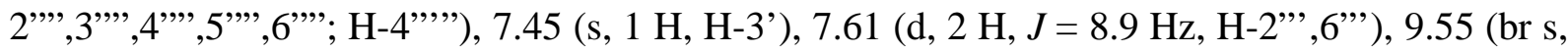
$1 \mathrm{H}, \mathrm{OH}) .{ }^{13} \mathrm{C}$ NMR (DMSO-d $\left.6,80^{\circ} \mathrm{C}\right) \delta 41.8(\mathrm{C}-4), 54.9\left(\mathrm{OCH}_{3}\right), 55.5(\mathrm{C}-5), 113.0(\mathrm{C}-2 ", 6 ”)$, 113.8 (C-3"',5"'), 115.7 (C-1'”'), 116.3 (C-3"'”'), 118.0 (C-4"), 118.8 (C-5"'”'), 122.9 (C-4' and C-2"',6"'”), 125.0 (C-1"'), 126.2 (C-4"”'), 126.7 (C-2"',6"'), 128.05 and 128.12 (C-3",5" and C-

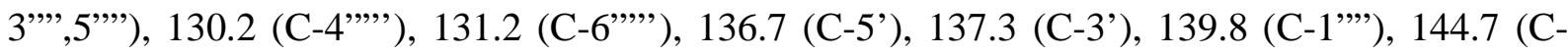
1 "'), 147.3 (C-3), 155.2 (C-2"'”'), 159.6 (C-4"”).

Diastereomeric mixture $-\mathrm{NMR}$ at $5^{\circ} \mathrm{C}$ :

Diastereomer A: ${ }^{1} \mathrm{H}$ NMR $\delta 3.10\left(\mathrm{dd}, 1 \mathrm{H}, J=6.8\right.$ and $\left.16.7 \mathrm{~Hz}, \mathrm{H}-4_{\text {trans }}\right), 3.51(\mathrm{dd}, 1 \mathrm{H}, J=12.4$ and $\left.16.7 \mathrm{~Hz}, \mathrm{H}-4_{\text {cis }}\right), 3.82\left(\mathrm{~s}, 3 \mathrm{H}, \mathrm{OCH}_{3}\right), 5.10(\mathrm{dd}, 1 \mathrm{H}, J=6.8$ and $12.4 \mathrm{~Hz}, \mathrm{H}-5), 5.20$ (br s, 1 $\mathrm{H}, \mathrm{OH})$.

Diastereomer B: ${ }^{1} \mathrm{H}$ NMR $\delta 3.15\left(\mathrm{dd}, 1 \mathrm{H}, J=7.5\right.$ and $\left.16.9 \mathrm{~Hz}, \mathrm{H}-4_{\text {trans }}\right), 3.46(\mathrm{dd}, 1 \mathrm{H}, J=12.2$ and $\left.16.9 \mathrm{~Hz}, \mathrm{H}-4_{c i s}\right), 3.82\left(\mathrm{~s}, 3 \mathrm{H}, \mathrm{OCH}_{3}\right), 4.93(\mathrm{dd}, 1 \mathrm{H}, J=7.5$ and $12.2 \mathrm{~Hz}, \mathrm{H}-5), 5.20$ (br s, 1 $\mathrm{H}, \mathrm{OH}$ ).

Diastereomers A+B: ${ }^{1} \mathrm{H}$ NMR $\delta$ 6.73-6.85 (m, $5 \mathrm{H}, 2 \mathrm{xH}-4$ ", H-3"”, and 2xH-5","'), 6.85-6.90 (m, 4 H, 2xH-3" ,5"'), 6.90-6.93 (m, 2 H, H-3"," and H-6"",'), 6.99-7.01 (m, 3 H, H-2",6" and

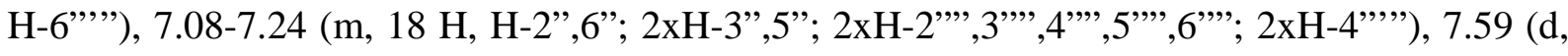
$2 \mathrm{H}, J=8.6 \mathrm{~Hz}, \mathrm{H}-2$ "', 6 "”), 7.60 (s, $1 \mathrm{H}, \mathrm{H}-3$ '), 7.61 (d, 2 H, $J=8.7 \mathrm{~Hz}, \mathrm{H}-2$ '”, 6"'), 7.63 (s, $1 \mathrm{H}$, H-3'). ${ }^{13} \mathrm{C}$ NMR $\delta 42.0$ and $42.5(\mathrm{C}-4), 55.3\left(\mathrm{OCH}_{3}\right), 55.6$ and $56.4(\mathrm{C}-5), 113.4$ and $113.9(\mathrm{C}-$ 2",6"), 113.8 (C-3"',5"'), 116.1, 116.4 and 116.6 (C-1"'"' and C-3"'"'), 118.8 and 119.3 (C-4"), 120.4 and 120.6 (C-5"'”'), 123.7 and 124.1 (C-2"',,6"'”), 124.0 and 124.3 (C-4'), 125.1 and 125.3 (C-1"'), 127.1 and 127.3 (C-2"',6”'), 127.3 (C-4"”'), 128.7 and 128.8 (C-3",5" and C-3"',5"'”), 
131.0 (C-4"'”), 131.3 and 131.6 (C-6"'”), 135.8 and 136.1 (C-5'), 138.4 and 139.3 (C-1"'), 138.6 and 139.1 (C-3'), 144.9 and 145.1 (C-1'), 147.2 and 148.3 (C-3), 153.9 and 154.4 (C2"’”), 159.8 and 159.9 (C-4"'). IR (cm $\left.{ }^{-1}\right): 1596,1498,1386,1252,1110,1068,1032,996,692$, 660; MS (EI $70 \mathrm{eV}): m / z(\%)=486\left(\mathrm{M}^{+}, 11\right), 394$ (2), 247 (19), 91 (100). Anal. Calcd. for $\mathrm{C}_{31} \mathrm{H}_{26} \mathrm{~N}_{4} \mathrm{O}_{2}$ : C, 76.52; H, 5.39; N, 11.51. Found: C, 76.44; H, 5.43; N, 11.60.

\section{3-(4-Fluorophenyl)-5-\{4-[5-(2-hydroxyphenyl)-1-phenylpyrazolyl]\}-1-phenyl-2-pyrazoline} (2d). Prepared as pale yellow needles in $71 \%$ yield, m.p. $136-137^{\circ} \mathrm{C}$.

Diastereomeric mixture $-\mathrm{NMR}$ at $5^{\circ} \mathrm{C}$ :

Diastereomer A: ${ }^{1} \mathrm{H}$ NMR $\delta 3.08\left(\mathrm{dd}, 1 \mathrm{H}, J=6.7\right.$ and $\left.17.0 \mathrm{~Hz}, \mathrm{H}-4_{\text {trans }}\right), 3.50(\mathrm{dd}, 1 \mathrm{H}, J=12.4$ and $17.0 \mathrm{~Hz}, \mathrm{H}-4_{\text {cis }}$ ), 5.08 (br s, $1 \mathrm{H}, \mathrm{OH}$ ), 5.15 (dd, $1 \mathrm{H}, J=6.7$ and $12.4 \mathrm{~Hz}, \mathrm{H}-5$ ).

Diastereomer B: ${ }^{1} \mathrm{H}$ NMR $\delta 3.14\left(\mathrm{dd}, 1 \mathrm{H}, J=7.1\right.$ and $\left.17.6 \mathrm{~Hz}, \mathrm{H}-4_{\text {trans }}\right), 3.41(\mathrm{dd}, 1 \mathrm{H}, J=12.5$ and $17.6 \mathrm{~Hz}, \mathrm{H}-4_{\text {cis }}$ ), 4.97 (dd, $1 \mathrm{H}, J=7.1$ and $12.5 \mathrm{~Hz}, \mathrm{H}-5$ ), 5.08 (br s, $1 \mathrm{H}, \mathrm{OH}$ ).

Diastereomers A+B: ${ }^{1} \mathrm{H}$ NMR $\delta$ 6.71-6.85 (m, $5 \mathrm{H}, 2 \mathrm{xH}-4$ ", H-3"”," and 2xH-5","), 6.88-6.98 (m, $3 \mathrm{H}, \mathrm{H}-3$ "'," and 2xH-6",'”), 6.98-7.01 (m, $2 \mathrm{H}, \mathrm{H}-2$ ", 6"), 7.04 (t, $4 \mathrm{H}, J=8.7 \mathrm{~Hz}, 2 \mathrm{xH}-$

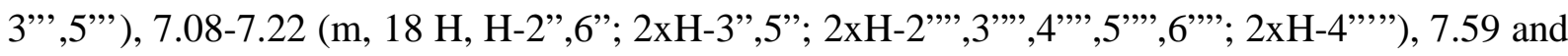
7.61 (2s, 2 H, 2xH-3'), 7.59-7.63 (m, 4 H, 2xH-2"',6"'). ${ }^{13} \mathrm{C}$ NMR $\delta 42.0$ and 42.3 (C-4), 55.8 and 56.3 (C-5), 113.5 and 113.7 (C-2",6"), 115.5 (d, ${ }^{2} J_{\mathrm{C}-\mathrm{F}}=21.8 \mathrm{~Hz}, \mathrm{C}-3$ "', ,5"'), 116.1, 116.3 and 116.6 (C-1"'”, and C-3"'”), 119.1 and 119.4 (C-4"), 120.3 and 120.6 (C-5"'”), 123.8 and 124.1 (C-2"”,6"'), 124.0 and 124.1 (C-4'), 127.4 (d, ${ }^{3} J_{\mathrm{C}-\mathrm{F}}=4.0 \mathrm{~Hz}, \mathrm{C}-2$ "”, 6"'), 127.4 and 127.5 (C-4"'”), 128.7 and 128.8 (C-3",5", C-1"' and C-3"',5"'”), 131.0 (C-4",'”), 131.3 and 131.7 (C6"'”), 136.1 and 136.5 (C-5'), 138.4 (C-3'), 139.1 and 139.3 (C-1"'”), 144.6 and 144.7 (C-1"), 146.1 and 147.0 (C-3), 154.0 and 154.6 (C-2'”'”), 162.8 (d, ${ }^{1} J_{\mathrm{C}-\mathrm{F}}=249.1 \mathrm{~Hz}, \mathrm{C}-4$ "'”). IR (cm $\left.{ }^{-1}\right)$ : 1598, 1498, 1386, 1268, 1178, 1110, 1042, 1032, 906, 712, 676, 660; MS (EI $70 \mathrm{eV}): \mathrm{m} / z(\%)=$ $474\left(\mathrm{M}^{+}, 23\right), 247$ (16), 91 (90), 77 (100). Anal. Calcd. for $\mathrm{C}_{30} \mathrm{H}_{23} \mathrm{FN}_{4} \mathrm{O}: \mathrm{C}, 75.93 ; \mathrm{H}, 4.88 ; \mathrm{N}$, 11.80. Found: C, 75.85; H, 4.94; N, 11.78 .

\section{3-(4-Chlorophenyl)-5-\{4-[5-(2-hydroxyphenyl)-1-phenylpyrazolyl]\}-1-phenyl-2-pyrazoline} (2e). Obtained as yellow plates in $73 \%$ yield, m.p. $145-146^{\circ} \mathrm{C}$.

Diastereomeric mixture $-\mathrm{NMR}$ at $5^{\circ} \mathrm{C}$ :

Diastereomer A: ${ }^{1} \mathrm{H}$ NMR $\delta 3.07\left(\mathrm{dd}, 1 \mathrm{H}, J=6.7\right.$ and $\left.16.9 \mathrm{~Hz}, \mathrm{H}-4_{\text {trans }}\right), 3.47(\mathrm{dd}, 1 \mathrm{H}, J=12.2$ and $16.9 \mathrm{~Hz}, \mathrm{H}-4_{\text {cis }}$ ), 5.16 (br s, $1 \mathrm{H}, \mathrm{OH}$ ), 5.17 (dd, $1 \mathrm{H}, J=6.7$ and $12.2 \mathrm{~Hz}, \mathrm{H}-5$ ).

Diastereomer B: ${ }^{1} \mathrm{H}$ NMR $\delta 3.13\left(\mathrm{dd}, 1 \mathrm{H}, J=7.1\right.$ and $\left.17.4 \mathrm{~Hz}, \mathrm{H}-4_{\text {trans }}\right), 3.42$ (dd, $1 \mathrm{H}, J=12.1$ and $17.4 \mathrm{~Hz}, \mathrm{H}-4_{\text {cis }}$ ), 4.98 (dd, $1 \mathrm{H}, J=7.1$ and $12.1 \mathrm{~Hz}, \mathrm{H}-5$ ), 5.16 (br s, $1 \mathrm{H}, \mathrm{OH}$ ).

Diastereomers A+B: ' $\mathrm{H}$ NMR $\delta 6.72$ (d, $1 \mathrm{H}, J=8.3 \mathrm{~Hz}, \mathrm{H}-3$ ", ”), 6.73-6.87 (m, $4 \mathrm{H}, 2 \mathrm{HH}-4$ " and 2xH-5","), 6.90 (d, $1 \mathrm{H}, J=8.3 \mathrm{~Hz}, \mathrm{H}-3$ "”,"), 6.98 (d, $2 \mathrm{H}, J=8.1 \mathrm{~Hz}, \mathrm{H}-2$ ",6"), 7.10-7.25

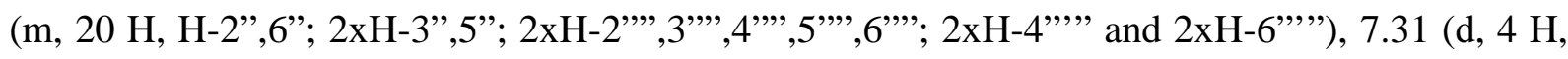
$J=8.6 \mathrm{~Hz}, 2 \mathrm{xH}-3$ "', 5"'), 7.55 (d, $4 \mathrm{H}, J=8.6 \mathrm{~Hz}, 2 \mathrm{xH}-2$ "', 6"'), 7.57 and 7.60 (2s, $2 \mathrm{H}, 2 \mathrm{xH}-3$ ').

${ }^{13} \mathrm{C}$ NMR $\delta 41.8$ and 42.0 (C-4), 55.7 and 56.2 (C-5), 113.5 and 113.7 (C-2”,6”), 116.0, 116.1, 116.2 and 116.4 (C-1"”, and C-3"'”'), 119.2 and 119.5 (C-4"), 120.4 and 120.6 (C-5"”'), 123.8 
and 124.1 (C-2"',6"'), 123.9 and 124.0 (C-4'), 126.7 and 126.8 (C-2"',6"'), 127.3 (C-4"”'), 128.6, 128.7 and 128.9 (C-3",5", C-3"',5", and C-3"',5"'”), 131.0 (C-1"'), 131.1 (C-4"'"'), 131.3 and 131.7 (C-6'"'), 134.0 and 134.1 (C-4"'), 136.1 and 136.4 (C-5'), 138.3 (C-3'), 139.0 and 139.3 (C-1"'”), 144.3 and 144.4 (C-1"), 145.8 and 146.6 (C-3), 153.9 and 154.5 (C-2'"')). IR (cm $\left.{ }^{1}\right): 1598,1500,1386,1266,1176,1154,1042,1032,938,854,708,662 ;$ MS (EI $\left.70 \mathrm{eV}\right): m / z(\%)$ $=490\left(\mathrm{M}^{+}, 14\right), 247(15), 91(81), 77$ (100). Anal. Calcd. for $\mathrm{C}_{30} \mathrm{H}_{23} \mathrm{ClN}_{4} \mathrm{O}: \mathrm{C}, 73.39 ; \mathrm{H}, 4.72 ; \mathrm{N}$, 11.41. Found: C, $73.47 ; \mathrm{H}, 4.67 ; \mathrm{N}, 11.48$.

5-\{4-[5-(2-Hydroxyphenyl)-1-phenylpyrazolyl]\}-3-(1-naphthyl)-1-phenyl-2-pyrazoline (2f). Prepared as white needles in $62 \%$ yield, m.p. $154-155^{\circ} \mathrm{C}$.

Diastereomeric mixture $-\mathrm{NMR}$ at $5^{\circ} \mathrm{C}$ :

Diastereomer A: ${ }^{1} \mathrm{H}$ NMR $\delta 3.35\left(\mathrm{dd}, 1 \mathrm{H}, J=6.5\right.$ and $\left.16.5 \mathrm{~Hz}, \mathrm{H}-4_{\text {trans }}\right), 3.76(\mathrm{dd}, 1 \mathrm{H}, J=12.0$ and $16.5 \mathrm{~Hz}, \mathrm{H}-4_{\text {cis }}$ ), 5.18 (dd, $1 \mathrm{H}, J=6.5$ and $\left.12.0 \mathrm{~Hz}, \mathrm{H}-5\right)$.

Diastereomer B: ${ }^{1} \mathrm{H}$ NMR $\delta 3.41\left(\mathrm{dd}, 1 \mathrm{H}, J=7.2\right.$ and $\left.17.0 \mathrm{~Hz}, \mathrm{H}-4_{\text {trans }}\right), 3.67(\mathrm{dd}, 1 \mathrm{H}, J=11.5$ and $17.0 \mathrm{~Hz}, \mathrm{H}-4_{\text {cis }}$ ), 4.99 (dd, $1 \mathrm{H}, J=7.2$ and $\left.11.5 \mathrm{~Hz}, \mathrm{H}-5\right)$.

Diastereomers A+B: ${ }^{1} \mathrm{H}$ NMR $\delta$ 6.73-6.76 (m 1 H, H-3","”), 6.80-6.85 (m, 2 H, 2xH-5"”,"), 6.926.99 (m, 3H, 2xH-4" and H-3"','), 7.08 (d, $2 \mathrm{H}, J=9.1 \mathrm{~Hz}, \mathrm{H}-2$ ", 6"), 7.12-7.25 (m, $20 \mathrm{H}$, , H2",6", 2xH-3",5"; 2xH-2",,3",,4",",5",,6"”; 2xH-4",", and 2xH-6","), 7.35-7.46 (m, 2 H, H-6", and 2xH-7"”), 7.46-7.53 (m, $1 \mathrm{H}, \mathrm{H}-6$ "”), 7.56 (d, $2 \mathrm{H}, J=7.1 \mathrm{~Hz}, 2 \mathrm{xH}-4$ "”), 7.64-7.69 (m, $2 \mathrm{H}$, 2xH-3"'), 7.64 and 7.66 (2s, $2 \mathrm{H}, \mathrm{H}-3$ '), 7.79 (br d, $2 \mathrm{H}, J=6.8 \mathrm{~Hz}, 2 \mathrm{xH}-8$ "'), 7.87 (d, $2 \mathrm{H}, J=$ $8.5 \mathrm{~Hz}, 2 \mathrm{xH}-5$ "'), 9.43 and 9.45 (2d, $2 \mathrm{H}, J=8.2 \mathrm{~Hz}, 2 \mathrm{xH}-2$ "') ${ }^{13}{ }^{13} \mathrm{C}$ NMR $\delta 44.4$ and 44.7 (C-4), 54.4 and 55.0 (C-5), 113.6 and 113.8 (C-2",6”), 116.1, 116.4, 116.5 and 116.6 (C-1"'” and C3'”'’), 119.1 and 119.5 (C-4"), 120.5 and 120.7 (C-5'”'”), 123.8 and 124.0 (C-4'), 123.9 and 124.1 (C-2"',6"'), 124.8 (C-4"' and C-6"'), 126.1 (C-7"'), 127.2 (C-2"', C-3"' and C-4"”), 128.5, 128.7, 128.8 and 128.9 (C-5"', C-3",5" and C-3"',5"'), 129.4 and 129.5 (C-8"'), 130.2 and 130.3 (C-1"'), 131.0 (C-4"'”), 131.4 and 131.5 (C-6"'”), 133.6 and 134.0 (C-4a"' and C8a"'), 136.0 and 136.3 (C-5'), 138.5 (C-3'), 139.2 and 139.3 (C-1"'), 144.4 and 144.7 (C-1"), 147.6 and 148.5 (C-3), 153.9 and 154.5 (C-2"'”'). IR ( $\left.\mathrm{cm}^{-1}\right)$ : 1596, 1498, 1380, 1292, 1176, 1142, 1032, 1020, 996, 910, 856, 718, 656; MS (EI $70 \mathrm{eV}): m / z(\%)=506\left(\mathrm{M}^{+}, 2\right), 247$ (44), 127 (74), 77 (100). Anal. Calcd. for $\mathrm{C}_{34} \mathrm{H}_{26} \mathrm{~N}_{4} \mathrm{O}$ : C, 80.61; H, 5.17; N, 11.05. Found: C, 80.53; H, 5.11; N, 11.10 .

5-\{4-[5-(2-Hydroxyphenyl)-1-phenylpyrazolyl]\}-3-(2-naphthyl)-1-phenyl-2-pyrazoline (2g). Isolated as white needles in $69 \%$ yield, m.p. $160-161^{\circ} \mathrm{C}$.

Diastereomeric mixture $-\mathrm{NMR}$ at $5^{\circ} \mathrm{C}$ :

Diastereomer A: ${ }^{1} \mathrm{H}$ NMR $\delta 3.27\left(\mathrm{dd}, 1 \mathrm{H}, J=6.6\right.$ and $\left.16.6 \mathrm{~Hz}, \mathrm{H}-4_{\text {trans }}\right), 3.67(\mathrm{dd}, 1 \mathrm{H}, J=11.9$ and $\left.16.9 \mathrm{~Hz}, \mathrm{H}-4_{\text {cis }}\right), 5.21$ (dd, $1 \mathrm{H}, J=6.6$ and $\left.11.9 \mathrm{~Hz}, \mathrm{H}-5\right)$.

Diastereomer B: ${ }^{1} \mathrm{H}$ NMR $\delta 3.32\left(\mathrm{dd}, 1 \mathrm{H}, J=7.1\right.$ and $\left.16.9 \mathrm{~Hz}, \mathrm{H}-4_{\text {trans }}\right), 3.61(\mathrm{dd}, 1 \mathrm{H}, J=11.5$ and $\left.16.6 \mathrm{~Hz}, \mathrm{H}-4_{c i s}\right), 5.05$ (dd, $1 \mathrm{H}, J=7.1$ and $\left.11.5 \mathrm{~Hz}, \mathrm{H}-5\right)$. 
Diastereomers A+B: ${ }^{1} \mathrm{H}$ NMR $\delta 6.74$ (d, $1 \mathrm{H}, J=7.8 \mathrm{~Hz}, \mathrm{H}-3$ ", ”), 6.76-6.91 (m, $4 \mathrm{H}, 2 \mathrm{xH}-4$ " and 2xH-5","), 6.93 (d, $1 \mathrm{H}, J=7.9 \mathrm{~Hz}, \mathrm{H}-3$ "”, ), 7.05 (d, $4 \mathrm{H}, J=8.1 \mathrm{~Hz}, \mathrm{H}-2$ ",6"), 7.13-7.24

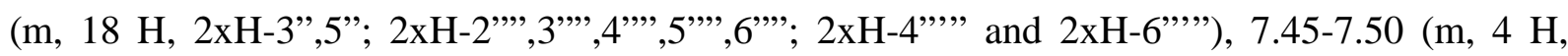
2xH-6"' and 2xH-7"'), 7.62 and 7.65 (2s, 2 H, H-3'), 7.72 (br s, 2 H, 2xH-1"'), 7.70-7.83 (m, 4 $\mathrm{H}, 2 \mathrm{xH}-5$ "' and 2xH-8"'), 7.82 (d, $2 \mathrm{H}, J=8.7 \mathrm{~Hz}, 2 \mathrm{xH}-4$ "'), 8.10 (dd, $2 \mathrm{H}, J=8.7$ and 1.5 $\mathrm{Hz}, 2 \mathrm{xH}-3$ "”). ${ }^{13} \mathrm{C}$ NMR $\delta 41.9$ and 42.1 (C-4), 55.7 and 56.2 (C-5), 113.6 and 113.8 (C-2",6"), 116.0, 116.1, 116.4 and 116.5 (C-1"'”' and C-3"'”'), 119.1 and 119.5 (C-4"), 120.5 and 120.7 (C5"'”), 123.4 and 123.7 (C-3"'), 123.95 and 124.09 (C-4'), 123.98 and 124.08 (C-2"',,6"'), 125.1 (C-1"'), 126.3 and 126.4 (C-6"' and C-7"'), 127.3 (C-4"'"), 127.8 and 128.0 (C-4"', C-5"' and C8"'), 128.7, 128.9 and 129.0 (C-3",5" and C-3"',5"'”), 131.0 (C-4"'”'), 131.3 and 131.7 (C-6","'), 133.0 and 133.2 (C-2"', C-4a"' and C-8a"'), 135.8 and 136.2 (C-5'), 138.5 and 138.6 (C-3'), 139.1 and 139.4 (C-1"''), 144.4 and 144.6 (C-1"), 147.1 and 147.9 (C-3), 153.9 and 154.4 (C2"'”). IR ( $\left.\mathrm{cm}^{-1}\right)$ : 1596, 1498, 1382, 1274, 1178, 1032, 1020, 996, 856, 718, 662; MS (EI $\left.70 \mathrm{eV}\right)$ : $m / z(\%)=506\left(\mathrm{M}^{+}, 18\right), 247(18), 91(87), 77$ (100). Anal. Calcd. for $\mathrm{C}_{34} \mathrm{H}_{26} \mathrm{~N}_{4} \mathrm{O}: \mathrm{C}, 80.61 ; \mathrm{H}$, 5.17; N, 11.05. Found. C, 80.67; H, 5.22; N, 11.12 .

\section{Acetylation of 3-aryl-5-\{4-[5-(2-hydroxyphenyl)-1-phenylpyrazolyl]\}-1-phenyl-2- pyrazolines $2 \mathrm{a}-\mathbf{c}, \mathbf{e}$}

A mixture of 3-aryl-5-\{4-[5-(2-hydroxyphenyl)-1-phenylpyrazolyl]\}-1-phenyl-2-pyrazolines 2ac,e $(1.0 \mathrm{mmol})$, acetic anhydride $(10.0 \mathrm{~mL})$ and anhydrous pyridine $(5.0 \mathrm{~mL})$ was refluxed for 6 hours, then poured onto crushed ice $(20 \mathrm{~g})$. The precipitate was filtered, washed with water $(3 \mathrm{x}$ $20 \mathrm{~mL}$ ) and recrystallized from methanol to afford 5-\{4-[5-(2-acetoxyphenyl)-1phenylpyrazolyl] \}-3-aryl-1-phenyl-2-pyrazolines 3a-c,e (Scheme 1).

5-\{4-[5-(2-Acetoxyphenyl)-1-phenylpyrazolyl]\}-1,3-diphenyl-2-pyrazoline (3a). Isolated as white needles in $82 \%$ yield, m.p. $157-158^{\circ} \mathrm{C}$.

\section{Diastereomeric mixture 53.5:46.5:}

Major diastereomer: ${ }^{1} \mathrm{H}$ NMR $\delta 2.05\left(\mathrm{~s}, 3 \mathrm{H}, \mathrm{CH}_{3}\right), 3.24(\mathrm{dd}, 1 \mathrm{H}, J=6.8$ and $16.7 \mathrm{~Hz}, \mathrm{H}-$ $\left.4_{\text {trans }}\right), 3.66\left(\mathrm{dd}, 1 \mathrm{H}, J=12.1\right.$ and $\left.16.7 \mathrm{~Hz}, \mathrm{H}-4_{\text {cis }}\right), 5.21(\mathrm{dd}, 1 \mathrm{H}, J=6.8$ and $12.1 \mathrm{~Hz}, \mathrm{H}-5)$, 6.78-6.84 (m, $1 \mathrm{H}, \mathrm{H}-4$ "), 7.09 (d, $2 \mathrm{H}, J=7.7 \mathrm{~Hz}, \mathrm{H}-2$ ",6"), 7.20 (t, $2 \mathrm{H}, J=7.7 \mathrm{~Hz}, \mathrm{H}-3$ ", 5”), 7.20-7.42 (m, 11 H, Ar), 7.43-7.52 (m, 1 H, H-4"'"'), 7.63 (s, $1 \mathrm{H}, \mathrm{H}-3$ '), 7.69-7.72 (m, $2 \mathrm{H}, \mathrm{H}-$ 2"',6”'). ${ }^{13}$ C NMR $\delta 20.8\left(\mathrm{CH}_{3}\right), 42.6$ (C-4), 55.9 (C-5), 113.6 (C-2",6”), 119.2 (C-4"), 123.37

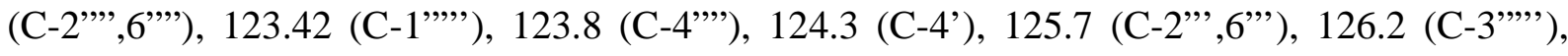

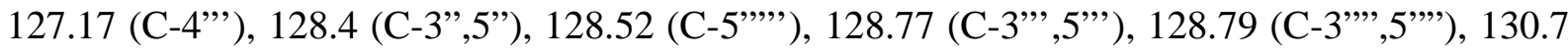

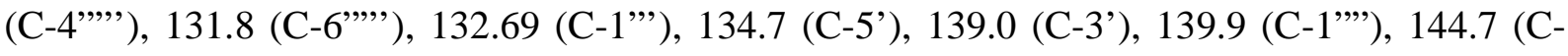
1"'), 147.0 (C-3), 148.3 (C-2"'”'), $168.3(\mathrm{C}=\mathrm{O})$.

Minor diastereomer: ${ }^{1} \mathrm{H}$ NMR $\delta 2.13\left(\mathrm{~s}, 3 \mathrm{H}, \mathrm{CH}_{3}\right), 3.22(\mathrm{dd}, 1 \mathrm{H}, J=6.9$ and $16.9 \mathrm{~Hz}, \mathrm{H}-$ $\left.4_{\text {trans }}\right), 3.74\left(\mathrm{dd}, 1 \mathrm{H}, J=11.9\right.$ and $\left.16.9 \mathrm{~Hz}, \mathrm{H}-4_{\text {cis }}\right), 5.13(\mathrm{dd}, 1 \mathrm{H}, J=6.9$ and $11.9 \mathrm{~Hz}, \mathrm{H}-5)$, 6.78-6.84 (m, 1 H, H-4"), 7.02 (d, 2 H, J = 7.7 Hz, H-2”,6”), 7.18 (t, 2 H, J = 7.7 Hz, H-3”,5”), 
7.20-7.42 (m, $11 \mathrm{H}, \mathrm{Ar}), 7.43-7.52$ (m, $1 \mathrm{H}, \mathrm{H}-4{ }^{\prime \prime \prime " ') ~} 7.67$ (s, $1 \mathrm{H}, \mathrm{H}-3$ ') $)$ 7.71-7.75 (m, $2 \mathrm{H}, \mathrm{H}-$ 2",6”). ${ }^{13}$ C NMR $\delta 20.9$ (CH $), 42.5$ (C-4), 56.2 (C-5), 113.9 (C-2",6”), 119.4 (C-4"), 122.9 (C-

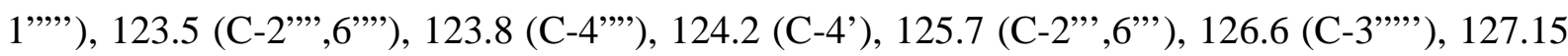

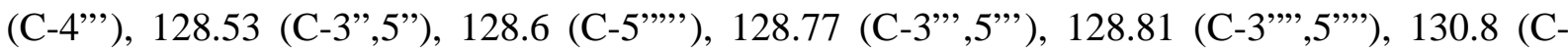
4"'”), 131.6 (6"'”), 132.73 (C-1"”), 134.5 (C-5'), 138.6 (C-3'), 139.6 (C-1"”'), 144.9 (C-1"), 147.3 (C-3), $149.0\left(\mathrm{C}-2^{\prime \prime \prime \prime \prime), ~} 168.6(\mathrm{C}=\mathrm{O})\right.$.

IR $\left(\mathrm{cm}^{-1}\right)$ : 1766, 1597, 1502, 1449, 1383, 1319, 1111, 1011, 910, 759, 692; MS (EI $\left.70 \mathrm{eV}\right)$ : $m / z(\%)=498\left(\mathrm{M}^{+}, 17\right), 455$ (5), 247 (12), 91 (100). Anal. Calcd. for $\mathrm{C}_{32} \mathrm{H}_{26} \mathrm{~N}_{4} \mathrm{O}_{2}: \mathrm{C}, 77.09 ; \mathrm{H}$, 5.26; N, 11.23. Found: C, 77.18; H, 5.32; N, 11.31.

\section{5-\{4-[5-(2-Acetoxyphenyl)-1-phenylpyrazolyl]\}-3-(4-methylphenyl)-1-phenyl-2-pyrazoline} (3b). Prepared as white needles in $83 \%$ yield, m.p. $197-198^{\circ} \mathrm{C}$.

\section{Diastereomeric mixture 54.4:45.6:}

Major diastereomer: ${ }^{1} \mathrm{H}$ NMR $\delta 2.05\left(\mathrm{~s}, 3 \mathrm{H}, \mathrm{CH}_{3}\right), 2.38\left(\mathrm{~s}, 3 \mathrm{H}, 4\right.$ ', ' $\left.-\mathrm{CH}_{3}\right), 3.22$ (dd, $1 \mathrm{H}, J=$ 6.9 and $\left.16.7 \mathrm{~Hz}, \mathrm{H}-4_{\text {trans }}\right), 3.64$ (dd, $1 \mathrm{H}, J=12.1$ and $\left.16.7 \mathrm{~Hz}, \mathrm{H}-4_{\text {cis }}\right), 5.17$ (dd, $1 \mathrm{H}, J=6.9$ and 12.1 Hz, H-5), 6.76-6.83 (m, $1 \mathrm{H}, \mathrm{H}-4$ "), 7.07 (dd, $2 \mathrm{H}, J=1.1$ and 8.9 Hz, H-2",6"), 7.14-7.34 (m, 12 H, Ar), 7.44-7.49 (m, 1 H, H-4"'”'), 7.66 (s, $\left.1 \mathrm{H}, \mathrm{H}-3^{\prime}\right), 7.60$ (d, $2 \mathrm{H}, J=8.3 \mathrm{~Hz}, \mathrm{H}-$ 2"',6”"). ${ }^{13} \mathrm{C}$ NMR $\delta 20.8\left(\mathrm{CH}_{3}\right), 21.4\left(4 "{ }^{\prime \prime}-\mathrm{CH}_{3}\right), 42.8$ (C-4), 55.8 (C-5), 113.6 (C-2",6"), 119.1 (C-4"), 123.44 (C-1"'”), 123.45 (C-2"',6"'), 123.8 (C-4"”), 124.4 (C-4'), 125.7 (C-2"',6"'), 126.2 (C-3"'”'), 127.1 (C-5"'”), 128.75, 128.77 and 128.81 (C-3"',5"' and C-3"',5"'), 129.17 (C-

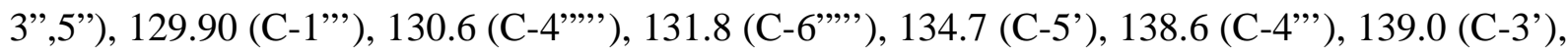
139.9 (C-1"'”), 144.9 (C-1"), 147.3 (C-3), 148.3 (C-2'"'”), 168.3 (C=O).

Minor diastereomer: ${ }^{1} \mathrm{H}$ NMR $\delta 2.13(\mathrm{~s}, 3 \mathrm{H}, \mathrm{CH}), 2.40\left(\mathrm{~s}, 3 \mathrm{H}, 4\right.$ ', ' $\left.-\mathrm{CH}_{3}\right), 3.20(\mathrm{dd}, 1 \mathrm{H}, J=$ 6.9 and $\left.16.9 \mathrm{~Hz}, \mathrm{H}-4_{\text {trans }}\right), 3.72\left(\mathrm{dd}, 1 \mathrm{H}, J=11.9\right.$ and $\left.16.9 \mathrm{~Hz}, \mathrm{H}-4_{\text {cis }}\right), 5.10$ (dd, $1 \mathrm{H}, J=6.9$ and $11.9 \mathrm{~Hz}, \mathrm{H}-5), 6.76-6.83$ (m, $1 \mathrm{H}, \mathrm{H}-4$ "), 7.01 (dd, $2 \mathrm{H}, J=1.2$ and 8.8 Hz, H-2",6”), 7.14-7.34 (m, 12 H, Ar), 7.44-7.49 (m, $1 \mathrm{H}, \mathrm{H}-4$ "'”'), 7.627 (d, $2 \mathrm{H}, J=8.3 \mathrm{~Hz}, \mathrm{H}-2$ "',6"'), 7.628 (s, $1 \mathrm{H}$, H-3'). ${ }^{13}$ C NMR $\delta 20.9\left(\mathrm{CH}_{3}\right), 21.4\left(4\right.$ "' $\left.-\mathrm{CH}_{3}\right), 42.6$ (C-4), 56.1 (C-5), 113.9 (C-2",6”), 119.2 (C-

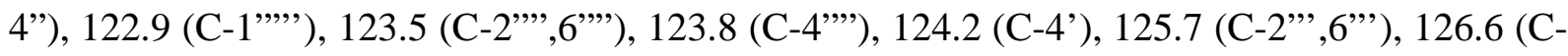
3"'”'), 127.2 (C-5"','), 128.75, 128.77 and 128.81 (C-3"',5"' and C-3"',5"'”), 129.23 (C-3",5"), 129.94 (C-1"'), 130.7 (C-4"'”'), 131.6 (C-6"'”), 134.5 (C-5'), 138.6 (C-4”’), 138.7 (C-3'), 139.6 (C-1"”'), 145.0 (C-1"), 147.5 (C-3), 149.0 (C-2"'”'), 168.6 (C=O).

IR $\left(\mathrm{cm}^{-1}\right):$ 1763, 1597, 1499, 1382, 1325, 1188, 1131, 1069, 910, 816, 764, 693; MS (EI $\left.70 \mathrm{eV}\right)$ : $m / z(\%)=512\left(\mathrm{M}^{+}, 24\right), 469(4), 247$ (15), 91 (100). Anal. Calcd. for $\mathrm{C}_{33} \mathrm{H}_{28} \mathrm{~N}_{4} \mathrm{O}_{2}: \mathrm{C}, 77.32 ; \mathrm{H}$, $5.51 ; \mathrm{N}, 10.92$. Found: C, 77.23; H, 5.46; N, 10.84 .

\section{5-\{4-[5-(2-Acetoxyphenyl)-1-phenylpyrazolyl]\}-3-(4-methoxyphenyl)-1-phenyl-2-pyrazoline} (3c). Isolated as white needles in $85 \%$ yield, m.p. $112-113^{\circ} \mathrm{C}$.

\section{Diastereomeric mixture 52.0:48.0:}

Major diastereomer: ${ }^{1} \mathrm{H}$ NMR $\delta 2.05\left(\mathrm{~s}, 3 \mathrm{H}, \mathrm{CH}_{3}\right), 3.20(\mathrm{dd}, 1 \mathrm{H}, J=6.9$ and $16.7 \mathrm{~Hz}, \mathrm{H}-$ $\left.4_{\text {trans }}\right), 3.62\left(\mathrm{dd}, 1 \mathrm{H}, J=12.0\right.$ and $\left.16.7 \mathrm{~Hz}, \mathrm{H}-4_{\text {cis }}\right), 3.85$ (s, $\left.3 \mathrm{H}, \mathrm{OCH}_{3}\right), 5.15$ (dd, $1 \mathrm{H}, J=6.9$ 
and $12.0 \mathrm{~Hz}, \mathrm{H}-5), 6.79$ (t, $1 \mathrm{H}, J=7.1 \mathrm{~Hz}, \mathrm{H}-4$ "), 6.91 (d, $2 \mathrm{H}, J=8.7 \mathrm{~Hz}, \mathrm{H}-3$ ', , ,5 ', ), 7.06 (d, $2 \mathrm{H}, J=8.2 \mathrm{~Hz}, \mathrm{H}-2$ ",6"), 7.14-7.34 (m, $10 \mathrm{H}, \mathrm{Ar}$ ), 7.43-7.51 (m, $1 \mathrm{H}, \mathrm{H}-4$ '”"'), 7.63 (s, $1 \mathrm{H}, \mathrm{H}-$ 3'), 7.64 (d, $2 \mathrm{H}, J=8.7 \mathrm{~Hz}, \mathrm{H}-2$ "', 6"' ). ${ }^{13} \mathrm{C}$ NMR $\delta 20.8\left(\mathrm{CH}_{3}\right), 42.8(\mathrm{C}-4), 55.3\left(\mathrm{OCH}_{3}\right), 55.9$

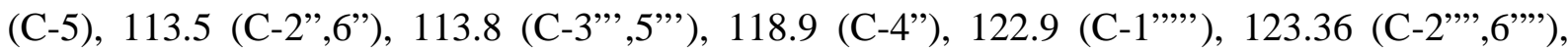
123.8 (C-4"'”), 124.5 (C-4'), 125.0 (C-1"”), 126.2 (C-3"'”), 127.2 (C-2"”,6”'), 128.76, 128.81

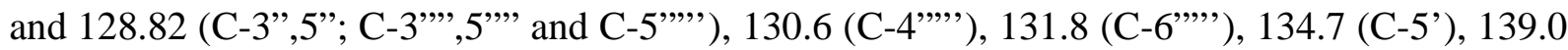
(C-3'), 139.9 (C-1"”'), 145.1 (C-1"), 147.1 (C-3), 148.3 (C-2'”"'), 160.1 (C-4"”), 168.3 (C=O).

Minor diastereomer: ${ }^{1} \mathrm{H}$ NMR $\delta 2.12\left(\mathrm{~s}, 3 \mathrm{H}, \mathrm{CH}_{3}\right), 3.17(\mathrm{dd}, 1 \mathrm{H}, J=7.1$ and $16.8 \mathrm{~Hz}, \mathrm{H}-$ $\left.4_{\text {trans }}\right), 3.70\left(\mathrm{dd}, 1 \mathrm{H}, J=11.8\right.$ and $\left.16.8 \mathrm{~Hz}, \mathrm{H}-4_{\text {cis }}\right), 3.86\left(\mathrm{~s}, 3 \mathrm{H}, \mathrm{OCH}_{3}\right), 5.07$ (dd, $1 \mathrm{H}, J=7.1$ and $11.8 \mathrm{~Hz}, \mathrm{H}-5), 6.79$ (t, $1 \mathrm{H}, J=7.1 \mathrm{~Hz}, \mathrm{H}-4$ "), 6.94 (d, $2 \mathrm{H}, J=8.7 \mathrm{~Hz}, \mathrm{H}-3$ ' ', ,5 ', ), 7.00 (d, $2 \mathrm{H}, J=8.2 \mathrm{~Hz}, \mathrm{H}-2$ ",6"), 7.14-7.34 (m, $10 \mathrm{H}, \mathrm{Ar}$ ), 7.43-7.51 (m, $1 \mathrm{H}, \mathrm{H}-4$ "”,'), 7.68 (s, $1 \mathrm{H}, \mathrm{H}-$ 3'), 7.65 (d, $2 \mathrm{H}, J=8.7 \mathrm{~Hz}, \mathrm{H}-2$ '”, 6"'). ${ }^{13} \mathrm{C}$ NMR $\delta 20.9\left(\mathrm{CH}_{3}\right), 42.7$ (C-4), $55.3\left(\mathrm{OCH}_{3}\right), 56.2$ (C-5), 113.9 (C-2",6"), 114.0 (C-3"”,5"”), 119.1 (C-4”), 122.8 (C-1","'), 123.44 (C-2"”,6"”), 124.0 (C-4"”'), 124.3 (C-4'), 126.0 (C-1"”), 126.6 (C-3"'”), 127.2 (C-2"”,6"'), 128.76, 128.81 and 128.82 (C-3",5"; C-3"',5"', and C-5"'”'), 130.7 (C-4"'”), 131.6 (6"'”), 134.5 (C-5'), 138.6 (C-3'), 139.6 (C-1'”'), 145.2 (C-1"), 147.4 (C-3), 148.6 (C-2"'”'), 160.0 (C-4"”), 168.6 (C=O).

IR $\left(\mathrm{cm}^{-1}\right): 1766,1597,1499,1384,1251,1190,1111,1034,910,832,762,693$; MS (EI $\left.70 \mathrm{eV}\right)$ : $m / z(\%)=528\left(\mathrm{M}^{+}, 20\right), 485$, (4), 247 (18), 91 (100). Anal. Calcd. for $\mathrm{C}_{33} \mathrm{H}_{28} \mathrm{~N}_{4} \mathrm{O}_{3}: \mathrm{C}, 74.98 ; \mathrm{H}$, 5.34; N, 10.59. Found: C, 74.89; H, 5.38; N, 10.50 .

\section{5-\{4-[5-(2-Acetoxyphenyl)-1-phenylpyrazolyl]\}-3-(4-chlorophenyl)-1-phenyl-2-pyrazoline} (3e). Obtained as pale yellow plates in $76 \%$ yield, m.p. $123-124^{\circ} \mathrm{C}$.

\section{Diastereomeric mixture 54.5:45.5:}

Major diastereomer: ${ }^{1} \mathrm{H}$ NMR $\delta 2.04\left(\mathrm{~s}, 3 \mathrm{H}, \mathrm{CH}_{3}\right), 3.19(\mathrm{dd}, 1 \mathrm{H}, J=6.9$ and $16.8 \mathrm{~Hz}, \mathrm{H}-$ $4_{\text {trans }}$ ), 3.62 (dd, $1 \mathrm{H}, J=12.3$ and $\left.16.8 \mathrm{~Hz}, \mathrm{H}-4_{\text {cis }}\right), 5.23$ (dd, $1 \mathrm{H}, J=6.9$ and $12.3 \mathrm{~Hz}, \mathrm{H}-5$ ), 6.79-6.85 (m, 1 H, H-4”), 7.08 (d, 2 H, J = 8.2 Hz, H-2",6”), 7.15-7.33 (m, 10 H, Ar), 7.34 (d, 2 H, $J=8.5 \mathrm{~Hz}, \mathrm{H}-3$ "', 5"'), 7.42-7.51 (m, $1 \mathrm{H}, \mathrm{H}-4$ "'”'), 7.61 (d, $2 \mathrm{H}, J=8.5 \mathrm{~Hz}, \mathrm{H}-2$ "',6"'), 7.62 (s, $1 \mathrm{H}, \mathrm{H}-3$ '). ${ }^{13} \mathrm{C}$ NMR $\delta 20.76\left(\mathrm{CH}_{3}\right), 42.4$ (C-4), 56.0 (C-5), 113.6 (C-2",6”), 119.4 (C-4”),

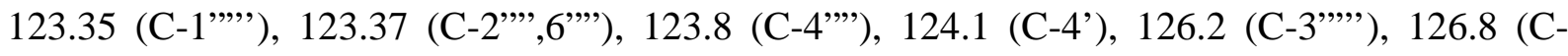
2", ,6"'), 127.24 (C-5",'), 128.6 (C-3"',5"'), 128.80 and 128.82 (C-3",5" and C-3"',5"'),130.7

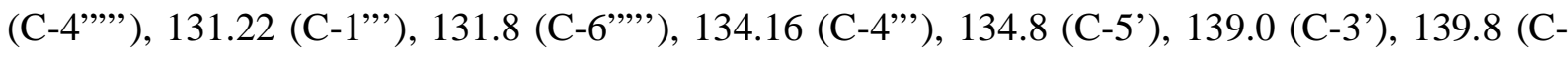
1"'”), 144.4 (C-1"), 145.9 (C-3), 148.3 (C-2"'”'), 168.3 (C=O).

Minor diastereomer: ${ }^{1} \mathrm{H}$ NMR $\delta 2.10\left(\mathrm{~s}, 3 \mathrm{H}, \mathrm{CH}_{3}\right), 3.16(\mathrm{dd}, 1 \mathrm{H}, J=7.1$ and $16.9 \mathrm{~Hz}, \mathrm{H}-$ $\left.4_{\text {trans }}\right), 3.68\left(\mathrm{dd}, 1 \mathrm{H}, J=12.0\right.$ and $\left.16.9 \mathrm{~Hz}, \mathrm{H}-4_{\text {cis }}\right), 5.15(\mathrm{dd}, 1 \mathrm{H}, J=7.1$ and $12.0 \mathrm{~Hz}, \mathrm{H}-5)$, 6.79-6.85 (m, 1 H, H-4”), 7.02 (d, 2 H, J = 8.2 Hz, H-2",6”), 7.15-7.33 (m, 10 H, Ar), 7.36 (d, 2 H, $J=8.4$ Hz, H-3"',5"'), 7.42-7.51 (m, 1 H, H-4"'”'), 7.64 (d, 2 H, J = 8.4 Hz, H-2'”,6"'), 7.65 (s, $1 \mathrm{H}, \mathrm{H}-3$ '). ${ }^{13} \mathrm{C}$ NMR $\delta 20.82\left(\mathrm{CH}_{3}\right), 42.3$ (C-4), 56.4 (C-5), 114.0 (C-2”,6”), 119.6 (C-4”), 122.8 (C-1"'”'), 123.5 (C-2"',6"'”), 123.8 (C-4"”'), 124.9 (C-4'), 126.6 (C-3"'”'), 126.8 (C-

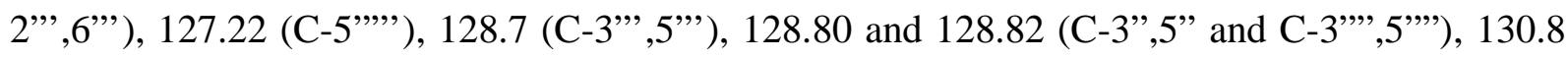




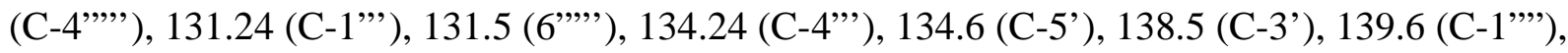
144.6 (C-1"), 146.1 (C-3), 148.9 (C-2'”'”), 168.6 (C=O).

IR $\left(\mathrm{cm}^{-1}\right): 1766,1598,1501,1453,1386,1322,1189,1090,1010,910,762,692 ;$ MS (EI $\left.70 \mathrm{eV}\right)$ : $m / z(\%)=532\left(\mathrm{M}^{+}, 16\right), 489(6), 247$ (16), 91 (100); Anal. Calcd. for $\mathrm{C}_{32} \mathrm{H}_{25} \mathrm{ClN}_{4} \mathrm{O}_{2}$ : C, 72.11; $\mathrm{H}$, $4.73 ; \mathrm{N}, 10.51$. Found: C, 72.21; H, 4.78; N, 10.43.

\section{Acknowledgements}

Thanks are due to the University of Aveiro, "Fundação para a Ciência e a Tecnologia" and FEDER for funding the Organic Chemistry Research Unit (project PEst-C/QUI/UI0062/2011) and the Portuguese National NMR Network (RNRMN). Our gratitude is also expressed to the Hungarian Scientific Research Fund (Grant No. T049468) for sponsoring the present study. Technical assistance of Mrs. M. Nagy is highly appreciated.

\section{References}

1. (a) Stanovnik, B.; Svete, J. Pyrazoles in Five-membered Hetarenes with Two Nitrogen or Phosphorus Atoms (Science of Synthesis), electronic version (Ed. Neier, R.), Georg Thieme Verlag, Stuttgart, 2002, Vol 12, p. 15-225. (b) Elguero, J.; Silva, A. M. S.; Tomé, A. C. Five Membered Heterocycles: 1,2-Azoles. Part 1. Pyrazoles in Modern Heterocyclic Chemistry (Eds. Alvarez-Builla, J. A.; Vaquero, J. J.; Barluenga, J.), Wiley-VCH, Weinheim, 2011, Chapter 8, Vol. 2, p. 635-725. (c) Fustero, S.; Sánchez-Roselló, M.; Barrio, P.; SimóonFuentes, A. Chem. Rev. 2011, 111, 6984-7034.

2. (a) Elguero, J. Pyrazoles (Ed. Shinkai, I.) in Comprehensive Heterocyclic Chemistry II (series Eds. Katritzky, A. R.; Rees, C. W.; Scriven, E. F. V.), Pergamon, Oxford, 1996, Vol. 3, 1-75. (b) Elguero, J.; Goya, P.; Jagerovic, N.; Silva, A. M. S. Pyrazoles as Drugs: Facts and Fantasies in Targets in Heterocyclic Systems, Italian Society of Chemistry, Rome, 2002, Vol. 6, p. 52-79. (c) Yet, L. Pyrazoles (Ed. Joule, J. A.) in Comprehensive Heterocyclic Chemistry III (series Eds. Katritzky, A. R.; Ramsden, C. A.; Scriven, E. F. V.; Taylor, R. J. K.), Elsevier, Oxford, 2008, Chapter 4.01, Vol. 4, 1-141.

3. (a) Polyakov, V.K.; Voronkin, V. M.; Tsukerman, S. V. Ukr. Khim. Zh. 1976, 42, 388-390. (b) Shankar, M. S. S.; Reddy, R. B.; Mouli, G. V. M.; Chandra, R Y. D. J. Indian Chem. Soc. 1989, 66, 30-31. (c) Coutinho, D. L. M. Indian J. Chem. 1992, 31B, 573-577.

4. (a) Lévai, A. Pharmazie 1981, 36, 449-450. (b) Lévai A. Heterocycl. Commun. 2002, 8, 375 580 .

5. Lévai, A. Monatsh. Chem. 1995, 126, 1245-1251. (b) Lévai, A.; Jekö, J. J. Heterocycl. Chem. 2002, 39, 1333-1366. 
6. Lévai, A.; Silva, A. M. S.; Pinto, D. C. G. A.; Cavaleiro, J. A. S.; Alkorta, I.; Elguero, J.; Jekö, J. Eur. J. Org. Chem. 2004, 4672-4679.

7. (a) Parsia, M. T. D.; Suárez, C.; Vitolo, M. J.; Márquez, V. E. J. Med. Chem. 1981, 24, 117 119. (b) Hurtado, I.; Urbina, C.; Suárez, C.; Beyer, B.; Magro, A. Int. J. Immunopharmacol. 1985, 7, 635-638.

8. Bendaha, H.; Yu, L.; Touzani, R.; Souane, R.; Giaever, G.; Nislow C.; Boone, C.; El Kadiri S.; Brown, G. W.; Bellaoui, M. Eur. J. Med. Chem. 2011, 46, 4117-4124.

9. Youssef, A. M.; Neeland, E. G.; Villanueva, E. B.; White, M. S.; El-Ashmawy, I. M.; Patrick, B; Klegeris, A.; Abd-El-Aziz, A. S. Bioorg. Med. Chem. 2010, 18, 5685-5996.

10. (a) Lee, H.H.; Boyd, M.; Gravatt, G. L.; Denny, W.A. Anticancer Drug Des. 1991, 6, 501 517. (b)Lin, R.; Chiu, G.; Yu, Y.; Connolly, P. J.; Li, S.; Lu, Y.; Adams, M.; FuentesPesquera, A. R.; Emanuel, S. L.; Greenberger, L. M. Bioorg. Med. Chem. Lett. 2007, 17, 4557-4561.

11. (a) Cuadro, A.M.; Elguero, J.; Navarro, P. Chem. Pharm. Bull. 1985, 33, 2535-2540. (b) Mayoral, E. P.; García-Amo, M.; López, P.; Soriano, E. Cerdán, S.; Ballesteros, P. Bioorg. Med. Chem. 2003, 11, 5555-5567.

12. Pinto, D. C. G. A.; Silva, A. M. S.; Cavaleiro, J. A. S.; Elguero, J. Eur. J. Org. Chem. 2003, 747-755.

13. The TLC control of the reaction mixture showed only the presence of the obtained 3-aryl-5\{4-[5-(2-hydroxyphenyl)-1-phenylpyrazolyl]\}-2-pyrazolines $\mathbf{2 a - g}$ and some degradation products.

14. The broadening of ${ }^{1} \mathrm{H}$ and ${ }^{13} \mathrm{C}$ NMR signals due to intramolecular hindered rotation is a wellknown situation (e.g. Pihlaja, K.; Kleinpeter, E. Carbon-13 NMR chemical shifts in structural and stereochemical analysis, VCH, New York, 1994, Chapter 6, p. 295-322), that led to atropisomers. In the present case, this phenomenon combined with the $\mathrm{C}-4$ stereocenter led to the formation of two diastereomers, situation that are to the best of our knowledge reported for the first time.

15. The $\mathrm{H}-4_{\text {cis }}$ and $\mathrm{H}-4_{\text {trans }}$ configurations are referred to their relative position to $\mathrm{H}-5$. 